\title{
Um Pensador da Democracia: A Ciência Política de Wanderley Guilherme dos Santos
}

\author{
Christian Edward Cyril Lynch \\ Professor do Instituto de Estudos Sociais e Políticos da Universidade do Estado do Rio de Janeiro \\ (IESP-UERJ) e da Universidade Veiga de Almeida (UVA). Pesquisador da Fundação Casa de Rui Barbosa \\ (FCRB), do Conselho Nacional de Desenvolvimento Científico e Tecnológico (CNPq) e da Fundação de \\ Amparo à Pesquisa do Estado do Rio de Janeiro (Faperj). \\ E-mail: clynch@iesp.uerj.br, https:/ / orcid.org/0000-0001-5709-9388
}

\section{INTRODUÇÃO}

\begin{abstract}
Com om sua morte em 25 de outubro de 2019, Wanderley Guilherme dos Santos entrou definitivamente para a história intelectual do Brasil como o principal fundador de sua moderna Ciência Política. Foi uma consagração que custou a acontecer por diversas razões, algumas prosaicas. Até recentemente, devido à sua juventude, os cientistas políticos davam pouca importância à história de constituição de sua própria área acadêmica de estudos, havendo poucos e esparsos estudos sobre o assunto (p. ex. Forjaz, 1997). Além disso, o próprio Wanderley se opunha à ideia de celebrar seus feitos. Associava os rituais de consagração ao reconhecimento implícito, por parte dos colegas, de obsolescência do homenageado. Também tinha horror à ideia de "fazer escola" à maneira francesa, meio pelo qual medíocres medalhões tentariam castrar a criatividade das novas gerações para criar para si uma legião de epígonos. Daí a cultura institucional de horizontalidade por ele introduzida no antigo Instituto Universitário de Pesquisas do Rio de Janeiro (IUPERJ, atual IESP-UERJ), bastante rara na academia brasileira de excelência. Liderança intelectual, para Wanderley, era algo que emergia naturalmente, ao longo de um regime de competição entre colegas, marcada pela liberdade e pela igualdade de condições. A insinuação de velhice física e mental embutida na noção de consagração acadêmica, implicando exames retrospectivos e balanços da trajetória intelectual, não condizia com sua personalidade enérgica e até certo ponto individualista. Por isso
\end{abstract}

DADOS, Rio de Janeiro, vol.63(1)e20200031, 2020. 
fazia questão de se apresentar diante dos colegas como um igual ou, na melhor das hipóteses, um primus inter paris, granjeando sua liderança através de pesquisas de ponta, criativas e audaciosas ${ }^{1}$. Os grandes prêmios que recebeu por sua obra, como aqueles concedidos pela Associação Brasileira de Ciência Política, pela Academia Brasileira de Letras e pela Casa das Américas, não o retiraram daquela posição. Não por acaso, aos 84 anos ele proferia conferências sobre o futuro das ciências sociais e ministrava um curso intitulado "Introdução ao século XXI". Da morte, não queria saber. Certa vez confessou a um amigo como queria sua lápide: "Aqui jaz Wanderley Guilherme dos Santos, sob protesto".

Não obstante, o reconhecimento público de seu lugar de centralidade na formação da área de Ciência Política do Brasil independia, até certo ponto, de sua vontade; e parece ter começado por volta de 2010. A proximidade da efeméride dos 50 anos de fundação dos primeiros programas de pós-graduação de ciência política levou os colegas a debruçaremse pela primeira vez de forma mais sistemática sobre o seu passado, produzindo balanços históricos mais densos (Avritzer, Milani e Braga, 2016). Ao mesmo tempo, surgiu a primeira geração de pesquisadores que, ao contrário das anteriores, não havia sido formada diretamente pelos pioneiros, já aposentados ou falecidos. $\mathrm{O}$ distanciamento passou a exigir uma produção de conhecimento objetivo que fosse além do memorialismo e das histórias de corredor. Acontecimento significativo para essa recuperação foi a passagem dos programas de pós-graduação do antigo IUPERJ, criados por Wanderley em 1969, para o âmbito do Instituto de Estudos Sociais e Políticos (IESP-UERJ). As dúvidas relativas à identidade da nova instituição, ocasionadas pela mudança de nome, suscitaram por parte de alguns de seus pesquisadores uma reflexão sobre suas origens. Por fim, ao longo da década de 2002-2010, durante o período de hegemonia da esquerda no cenário nacional, houve a reabilitação do papel intelectual exercido pelo antigo Instituto Superior de Estudos Brasileiros (ISEB) - extinto em 1964 pelo regime militar, e do qual o jovem Wanderley havia sido o último grande expoente. A consagração formal parece ter começado em 2013, quando ele recebeu o prêmio Gildo Marçal Brandão de excelência acadêmica, concedido então pela Associação Nacional de Pós-Graduação e Pesquisa em Ciências Sociais (Anpocs) pela primeira vez. Surgiram os primeiros estudos dedicados à sua obra, como a coletânea organizada por Otávio Dulci e denominada Leituras críticas sobre Wanderley Guilherme dos Santos (Dulci, 2013); e o volume Encontros: Wanderley Guilherme dos Santos, 
organizado por Amélia Cohn (2015). Apareceram também artigos dedicados à sua obra, voltados para a análise de sua contribuição ao estudo do pensamento político brasileiro e à teoria da democracia (Lynch, 2013; Moreira, 2014). Em 2015 teve lugar no IESP-UERJ o seminário Homenagem a Wanderley Guilherme dos Santos, comemorativo de seus 80 anos. Quatro anos depois, ele já era a personagem central dos festejos relativos ao cinquentenário dos programas de pós-graduação do instituto. À maneira de Guimarães Rosa, que morreu ao tomar posse na Academia Brasileira, Wanderley Guilherme faleceu um mês depois da consagração que sempre quis evitar.

Esse artigo propõe apresentar, pela primeira vez, uma visão lógicosistemática de conjunto da ciência política de Wanderley Guilherme dos Santos (doravante, WGS). Por visão lógico-sistemático, entendese aqui aquela caracterizada pela precedência da construção interna dos níveis de conhecimento - epistemologia, teoria, empiria etc. -, em detrimento de uma exposição histórico-cronológica. Há boas razões para a escolha. Em primeiro lugar, existe pouca literatura acumulada sobre o conjunto de sua obra, e a maior parte dela se ocupa de questões intelectuais e institucionais vinculadas à política brasileira. Em segundo lugar, há no prelo um livro de Marcelo Sevaybricker Moreira dedicado ao "pensamento político" de WGS, encarado como um "intérprete do Brasil" (Moreira, 2020), razão adicional para não "chover no molhado". Em terceiro lugar, e talvez mais importante, encontra-se o fato de que, como cientista político, WGS se via primariamente como um teórico que recorria à empiria para testar suas hipóteses. Inclemente crítico do complexo de inferioridade que rebaixa sistematicamente a ambição teórica dos intelectuais brasileiros, WGS desenvolveu uma ciência política abrangente, capaz de ser demonstrada de forma sistemática e aplicável a qualquer país. Não obstante a maioria de suas reflexões tenha por origem os problemas empíricos da construção democrática brasileira, ele sempre evitou tomá-los como "jabuticabas", evitando simultaneamente o paroquialismo etnocêntrico, disfarçado de universalismo, de boa parte dos intelectuais europeus e norte-americanos. $\mathrm{O}$ artigo examina quatro pontos de sua ciência política: 1) Filosofia social, em suas dimensões ontológica e epistemológica; 2) Teoria política, descrevendo o papel dos clássicos e dos modernos; 3) Teoria da mudança política, contando com uma tipologia de regimes, suas modalidades de trânsito de um para outro, bem como as hipóteses de reforma e ruptura; e 4) Teoria da democracia, contemplada em suas 
três dimensões: integração, participação e redistribuição. Acredito que a ligeireza com que apresentarei a ciência política de WGS possa ser compensada pelo oferecimento de uma visão de seu conjunto, que pode ser útil aos colegas interessados em desdobrar, aprofundar ou questionar os pontos aqui ventilados. Isso pode ser especialmente útil em sua aplicação ao caso brasileiro, em suas obras maiores de interpretação: Razões da desordem (1993), Décadas de espanto e uma apologia democrática (1998) e Horizonte do desejo: instabilidade, fracasso coletivo e inércia social (2004).

\section{FILOSOFIA SOCIAL: ONTOLOGIA CÉTICA E EPISTEMOLOGIA CIENTÍFICA}

\section{Ceticismo moderado como antídoto ao dogmatismo}

O melhor ponto de partida para entender a ciência política de WGS é sua filosofia social, uma vez que ela fornece o seu quadro ontológico e epistemológico essencial. Trata-se de uma filosofia que vê o mundo por um prisma moderadamente cético, destacando a dificuldade de compreender os fenômenos sociais, mas também o papel produtivo da ignorância na sua confecção. Seu pensamento se contrapõe às perspectivas dogmáticas do positivismo, do marxismo e do economicismo da escolha racional, que acreditam na possibilidade de conhecimento objetivo do conjunto da realidade ${ }^{2}$. São escolas que apresentam o mundo social como um sistema fechado e estável de causalidades impostas pela necessidade, passível de cognição por esquemas classificatórios e leis despojadas de mediações subjetivas. A concepção dogmática do mundo social como um sistema fechado é denunciada por WGS, que se recusava a reconhecer a existência de fontes de variações causais autônomas, irredutíveis a explicações sistemáticas. Ela não explica como uma ordem social, supostamente regulada de modo impessoal, se concilia com o fato de que a liberdade humana, no nível individual, produz inovações imprevistas no agregado da referida ordem. Para WGS, era impossível "encarcerar" as diversas possibilidades de mundo engendráveis pela subjetividade humana dentro de explicações totalizantes. As teorias dogmáticas só pareciam funcionar a respeito de fenômenos muito específicos da realidade. Por todas essas razões, ele preferia partir de um ceticismo filosófico moderado, que concebe a ordem social de modo mais flexível: 


\section{Christian Edward Cyril Lynch}

A ordem social é regulada por um sistema relativamente estável de causalidades, aberto, entretanto, as avaliações produzidas por fontes autônomas e pelo compromisso com a hipótese de que a lógica de apreensão desse sistema está, necessariamente, contaminada pelo arbítrio da subjetividade contida na definição dos conceitos básicos que organizam a representação do mundo. [...] Considerar a ordem social como um sistema aberto obriga ao reconhecimento de que nem todos os processos capazes de produzir variações em dado sistema de causalidades sejam, eles próprios, suscetíveis de explicações, ou reduções causais, sistemáticas (Santos, 1979:12).

\section{A mão invisível do caos: representações subjetivas do mundo, autointeresse e 0 imprevisto criativo da ação coletiva}

Para WGS, aquilo que os dogmáticos representavam como produto da regularidade social não derivava da necessidade, resultando do exercício rotineiro de comportamentos aprendidos e disseminados. As ações pessoais não decorreriam do conhecimento objetivo do mundo, mas de suas representações da realidade, produzidas pela sensação do acontecer e pela projeção, nelas, de seus desejos particulares. O consenso sobre as coisas, amplo ou durável, não servia para aferir a verdade objetiva das coisas. Nem a lição da experiência, que se resumiria a um registro do precário:

\footnotetext{
Osujeito se faz uma ideia de como a realidade deveria ser e, então, representa a realidade como ela precisa ser para poder servir como premissa material, prática, a partir da qual se possa validar (tornar verdadeira) a inferência que conduz à conclusão descritiva de como a realidade deve tornar-se (Santos, 1990:15).
}

A realidade enquanto premissa e a realidade enquanto conclusão seriam, por conseguinte, "os dois principais nexos associando representações (subjetividade) e mundo profano (objetividade)" (Santos, 1990a:15). Da mesma forma, nem sempre as mesmas causas produziriam os mesmos efeitos: “O princípio da indeterminação da subjetividade implica a negação de que a objetividade seja redutível, completa e consistentemente, ao sistema conceitual fechado" (Santos, 1988a:28). A ordem social seria o resultado agregado de microprocessos que, olhados de perto, não seguiriam a mesma lógica: cada ator social se movimentava conforme diferentes percepções da realidade, gerando resultados imprevisíveis no conjunto. WGS 
propunha uma ontologia social alternativa, orientada por um princípio de razões e efeitos contingentes: "Tudo aquilo que existe poderia, pela mesma razão que existe, não existir; tudo aquilo que existe por alguma razão poderia existir por alguma outra razão" (Santos, 1990a:34; ênfases do original). Seria impossível tudo antecipar e tudo que era antecipado seria possível. Dada a precariedade do conhecimento, todo argumento social era necessariamente provisório. Suas raízes se perderiam na sombra da ignorância e do imprevisível.

Na carência de uma harmonia preestabelecida, o que prevaleceria no ordenamento do mundo era "o princípio da mão invisível do caos, gerador do acaso, do imprevisível e do horrível" (Santos, 1990a:80). O conteúdo cognitivo da ação social seria ínfimo, e a estabilidade e a mudança, produtos involuntários da ignorância sobre o funcionamento do real. A ação humana seria pouco eficaz e de difícil capacidade preditiva, porque raramente se orientava conforme uma representação adequada dos fatos. $\mathrm{O}$ avanço do conhecimento geraria sempre maior consciência do quanto se desconhecia. Mas o reconhecimento da impossibilidade de tudo conhecer não deveria nos conduzir a um estado de desespero ou abulia. Era justamente a radical indeterminação do real que permitia a cooperação social e a ordem política. Os agentes sociais absorviam e processavam experiências e, frequentemente, surpreendiam os demais com respostas novas diante de situações idênticas. Porque constituía condição de liberdade e criatividade individual, a ignorância social era uma dádiva: ela estava na origem e era, ao mesmo tempo, efeito dos mais espetaculares resultados imprevistos dos cálculos racionais. A própria história só era possível porque os agentes se representavam ordens objetivas distintas e buscavam modificar o status quo a partir delas. A dinâmica social quedaria paralisada se todos os atores pudessem prever o comportamento dos outros, transcendendo a particularidade de seus pontos de vista e prevendo o efeito agregado da somatória das ações individuais. A própria mudança social só podia ser explicada como um resultado das transmutações imprevistas e incontroláveis processadas pela subjetividade humana. $\mathrm{O}$ reconhecimento da impossibilidade de tudo conhecer sublinhava, ademais, a importância do valor da tolerância, verdadeira lição da consciência dos limites de si mesmo (Santos, 1978:13). 
Ciência rigorosa como resposta à precariedade do conhecimento

A consciência da precariedade dos sentidos em apreender objetivamente os fenômenos do mundo real não deveria nos desestimular a conhecê-los: "Viver em ignorância é condição ontológica, mas optar pela ignorância é perversão epistemológica" (Santos, 1990b:13). Para WGS, "a aventura do espírito, do mesmo modo que a aventura da ação, requer a coragem de enfrentar o risco do ignoto e a humildade de aceitar a plausibilidade do fracasso" (Santos, 1978:12). Em vez de abater o cientista, a consciência da ignorância deveria estimulá-lo a aperfeiçoar continuamente suas teorias e técnicas de conhecimento da realidade: "O poder de uma teoria manifesta-se no universo que ela nos permite compreender e na extensão do que nos impede ver" (Santos, 1998b:12). Neste sentido, sua admiração pelas categorias de artesanato intelectual e imaginação sociológica, formuladas por Wright Mills, não era incompatível com sua exigência de uma ciência social rigorosa. Wanderley pensava a ciência como uma espécie de artesanato intelectual, entendendo que as hipóteses de trabalho surgem da criatividade do cientista. Nem por isso se furtava de demonstrá-las teórica e metodologicamente, elaborando hipóteses adequadas acerca de objetos bem definidos, e distinguindo entre ciência e normatividade (Santos, 1971:73). A hipótese de trabalho deveria se basear no juízo de probabilidade do pesquisador, e ser comprovada recorrendo ao espírito da filosofia analítica e da lógica matemática. As correlações empíricas deveriam ser previamente filtradas pelo crivo da comparação com correlações empíricas contrárias, a fim de passarem no teste de falseabilidade (Santos, 1967:137). Nessa busca pelo rigor científico, a famosa querela entre métodos quantitativos e qualitativos não fazia nenhum sentido para WGS: ambos constituíam recursos ao conhecimento objetivo da realidade. Questões de método também não esgotavam as alternativas nem os problemas da ciência (Santos, 1965:90-91). A artificial separação entre as duas esferas, a teórica e a empírica, resultava em uma divisão esterilizante do campo científico: de um lado, cultores de doutrinas alheias, incapazes de teorizarem por si mesmos; de outro, redundantes empiristas dogmáticos, que produziam dezenas de artigos para comprovar obviedades (Santos, 2007b:11). 


\title{
TEORIA POLÍTICA: INSTITUIÇÕES, AÇÃO COLETIVA E POLIARQUIA
}

\author{
A teoria da escolha pública: uma adesão crítica
}

Como os demais membros da primeira geração de "novos" cientistas políticos, após o regime militar WGS abandonou a antiga orientação dialético-marxista de argumentação de seus tempos do ISEB. Autores como Marx, Engels e Lenin deveriam continuar a ser lidos, mas não como referências científicas contemporâneas (Santos, 1990a:19-27). No lugar do marxismo, entrava a teoria da escolha pública, formulada por Kenneth Arrow e Anthony Downs, que transpunha para a política modelos elaborados pela teoria econômica. A teoria da escolha pública pressupunha a racionalidade dos atores políticos, que agiriam de modo a maximizar seus resultados em situações de múltipla possibilidade de escolhas. A competição política ocorreria pela manipulação de recursos escassos, como voto, dinheiro, coação, saber técnico e informação, com os objetivos de acumular poder, status e riqueza. A linguagem lógico-formal dessa escola, que representava preferências individuais em notações matemáticas típicas dos modelos de microeconomia, aparece com frequência na obra de WGS como parte do esforço de validação de suas proposições teóricas. No entanto, sua absorção dessa literatura não foi acrítica. Ela foi filtrada pelo desejo de se afastar das versões deterministas do economicismo. Na defesa do rigor e da criatividade, o pensamento antidogmático de WGS condenava todos os "intolerantes fundamentalismos do funcionalismo, behaviorismo, etnometodologia, interacionismo simbólico, análise sistêmica, além das recém-chegadas análises neoinstitucionalistas e da escolha racional" (2003:20). Seu libelo contra as ortodoxias esterilizantes concluía com uma sentença terminante: "Quanto menos contribuição substantiva interessante alguém tem a dar, mais procura impor, aos outros, facciosas algemas escolásticas" (Santos, 2003:21) ${ }^{3}$. O abandono do marxismo-leninismo por WGS não deve ser interpretado, portanto, como uma abdicação de ideais igualitários e nacionalistas de sua juventude. Ele fazia parte de uma crítica mais ampla a todas as abordagens que negassem a autonomia relativa da política como domínio do saber ${ }^{4}$.

\section{Autonomia relativa das instituições e interdisciplinaridade}

Desde a ascensão das análises sociológicas e econômicas, por volta de 1930, os analistas haviam se habituado a encarar os fenômenos políticos como epifenômenos do domínio socioeconômico. Essa postura 
decorria de uma crítica sociológica ao formalismo jurídico pelo qual a "velha" ciência política estudava as instituições. Era dever da "nova ciência política", pois, recuperar a dignidade e autonomia daquele domínio. Para tanto, cumpria evitar o antigo formalismo, refutando, porém, a condição subalterna ou dependente da ciência política como saber. Foi o que WGS fez em sua tese de doutorado:

A dinâmica da competição política entre partidos, e de facções dentro dos partidos, não representa apenas um balé metafórico daquilo que ocorre na economia. [...]. Os processos sociais e econômicos são sempre mediados pelas instituições políticas existentes (Santos, 1986:21).

Salientando a conexão entre os diversos domínios do saber, cuja autonomia existia sempre de modo relativo, WGS entendia que as demais ciências deveriam ser cultivadas pelo cientista político como suas auxiliares. Uma ciência política inteligente jamais poderia dispensar o recurso à interdisciplinaridade, que lhe parecia necessário para compensar "a política descarnada da teoria da escolha racional" (Santos, 2017a:119). Sem bem conhecer história, economia, sociologia ou psicologia, o cientista político não tinha como desempenhar a contento seu papel de analista e pesquisador: "Se não é razoável exigir que cada profissional examine holisticamente os fenômenos, robustecer análises particulares com contribuições de disciplinas conexas favorece o entendimento do fenômeno" (Santos, 2017a:146). Entre aqueles diversos domínios do saber, aquele que WGS mais parece ter valorizado na maturidade parece ter sido a História ${ }^{5}$ Ela ensinava, tanto quanto a filosofia, os limites possíveis da cognição humana:

Por meio da história a teoria se faz vida, orientando-se esta por conceitos, crenças, associações suspeitas e, às vezes, por destroços de segmentos causais. Quando alguma investigação teórica se completa é porque existe esperança de que certos fragmentos causais tenham sido capturados. Mas é a resistência das conclusões às ameaças de desmentido com a coerente incorporação destas ao fluir do tempo, como seu enredo implícito, que garantem a fertilidade do compromisso entre teoria e história (Santos, 2003:17). 
Papel dos clássicos da ciência política

Platão, Aristóteles e seus sucessores haviam formulado modelos de mundos possíveis, ou seja, sofisticadas representações da realidade, de longa influência e relevância na cultura ocidental. Ao longo de seus escritos, percebe-se a maior afinidade de WGS com os teóricos ditos "realistas", que descreviam os fenômenos sociais a partir da mesma visão cética moderada do mundo e das possibilidades de conhecê-lo. Ele apreciava em especial os expoentes do Iluminismo britânico, como Hume, Ferguson, Smith e Burke, que ao seu juízo teriam interpretado magnificamente as transformações e dilemas do advento da sociedade comercial (Araújo, 2019:157). Nem por isso o estudo dos clássicos deveria ser encarado como um fim em si, ou seja, como mera filosofia ou história das ideias. Conforme já referido, WGS era cético acerca da veracidade de qualquer sistema filosófico sistemático: "Conhecer a doutrina de $X$ não significa saber alguma coisa do mundo além da doutrina de $X$, que está neste mundo" (Santos, 1990a:7). O papel dos clássicos era o de servir de apoio para que o cientista político pudesse pensar o mundo contemporâneo com a própria cabeça. Cada sociedade havia sido conformada por diferentes modos de organização, lidando com problemas dentro de suas respectivas configurações históricas e culturais. Os clássicos os haviam enfrentado recorrendo à ciência disponível em suas épocas, e cabia aos contemporâneos não ficar abaixo. Ademais, o objeto da ciência política contemporânea era a democracia, regime relativamente recente sobre os quais a maioria dos clássicos tinham pouco a dizer. Embora Mill, Marx e Tocqueville a tivessem entrevisto surgir no horizonte, os primeiros a vê-la de perto teriam sido Mosca, Michels e Pareto $^{6}$. Na prática, WGS teorizava a partir de clássicos e modernos, divergindo ou concordando, e sem conferir superioridade intrínseca a nenhum. Eram todos instrumentos de sua própria teorização.

Papel dos modernos da ciência política (1): a contribuição de Buchanan e Tullock

A despeito de seu diálogo com as obras de outros autores, como Giovanni Sartori e Alessandro Pizzorno (Anastasia, 2013:95), eram principalmente três aquelas que, para WGS, constituíam "o núcleo nobre da teoria política da democracia representativa contemporânea" (Santos, 2019a:18-19). Em primeiro lugar estava O cálculo do consenso: fundações lógicas da democracia constitucional (1962), de James Buchanan e Gordon Tullock. Os dois autores explicavam que somen- 
te decisões unânimes afastavam os riscos individuais de externalidades negativas, e que todas as demais, ainda que tomadas por maioria, não produziam decisões satisfatórias para uns sem descontentar a outros. Ao estimular a proliferação de interesses organizados, a democracia aumentava o número de descontentes, independentemente do bem-estar presente. Dessa "análise lógica, rigorosa e bela dos modelos racionais", de "extraordinário poder analítico", WGS extraiu o essencial sobre o funcionamento das instituições (Santos, 2017a:151; 2019:18). As reflexões de Buchanan sobre as condições para a formação do consenso democrático, somadas àquelas de Sartori sobre o funcionamento dos sistemas partidários, serviram para que WGS elaborasse, em Sessenta e quatro (1986), sua própria teoria da crise política. Na contramão do "cálculo do consenso", ela explicava como a polarização política, em um contexto de dispersão de recursos e exacerbada radicalização entre os atores, podia abater a democracia pela via da ruptura. Tratava-se de uma situação de equilíbrio de poder que gerava o fenômeno da paralisia decisória, na qual

nenhum ator (ou coalizão de atores) é capaz de impor suas preferências sobre os outros, devido à forma particular da distribuição de recursos, somada a um grau extremamente alto de intensidade de preferências em relação à questão. Consequentemente, nenhuma decisão pode ser tomada ou, se puder ser simbolicamente tomada, não será possível ser implementada (Santos, 1986:172).

Era preciso fazer não só o "cálculo do consenso", mas também o "cálculo do conflito". A partir de Buchanan e Tullock, pois, WGS desenvolveu outros dois conceitos: o do cálculo do dissenso, que orientava o gestor em matéria de políticas públicas; e o de estabilidade governamental, que permitia aferir comparativamente períodos de maior ou menor estabilidade a partir da rotação dos ministros nas pastas governamentais (Santos, 1979:127; 1986:116).

\section{Papel dos modernos da ciência política (2): a contribuição de Mancur Olson}

A segunda obra seminal era A lógica da ação coletiva (1965), de Mancur Olson. Ao contrário do que supunha extensa literatura, Olson demonstrava que a cooperação social em grande escala era incapaz de produzir bens coletivos; isto é, bens que, sendo gozados por todos, não podiam excluir de sua fruição aqueles que não houvessem concorrido para sua produção. Afinal, por que alguém haveria de 
arcar com ônus de contribuir para a produção de um bem que, no final das contas, qualquer um teria o direito de fruir? Não havia altruísmo, da simpatia ou identidade de interesses que resolvesse a questão. A cooperação social em larga escala só era viável, de acordo com Olson, em duas hipóteses: ou quando empregava a coerção para mobilizar os indivíduos, ou quando oferecia vantagens adicionais àqueles que se engajassem. Por outro lado, WGS acreditava que a teoria de Olson era insuficiente em certos aspectos. Ela não explicava como surgia a cooperação, quando as organizações ainda não dispunham de recursos para recorrer aos incentivos extras como vantagens laterais ou coação. Em A lógica dual da ação coletiva (1989), WGS sugere que a iniciativa de produção do bem coletivo apareceria sempre que, independentemente da cooperação de terceiros, os custos de não o produzir fossem maiores que os de produzi-lo ${ }^{7}$. Para tanto, ele desenvolveu o conceito de mal público: ao contrário do bem público, cuja oferta era universal, e o consumo, opcional, o mal público se caracterizava pela impossibilidade de não o consumir, mesmo contra a vontade. A necessidade de livrar-se do mal público estava, portanto, na raiz da ação coletiva. WGS também chama a atenção para a lógica cooperativa dos movimentos sociais, religiosos ou laicos, resistentes ao cálculo de interesse individual. Para tanto, ele elaborou em O paradoxo das igrejas (2019) o conceito de bem público privado para designar bens como a salvação ou a identidade social, cujos custos de produção eram pelo menos equivalentes aos benefícios de sua fruição. Quanto mais vasto o consumo coletivo, maiores as recompensas de sua produção individual (Santos, 2019a:133).

\section{Papel dos modernos da ciência política (3): a contribuição de Robert Dahl}

A terceira obra decisiva para a ciência política de WGS era Poliarquia: participação e oposição (1971), de Robert Dahl. Ela lhe permitia pensar a democracia como um fenômeno dinâmico, revelando "um rasto dos caminhos que a democracia pode trilhar para se estabelecer e, pois é obra humana, também para desmoronar" (Santos, 2014:289). Dahl ensinava que a democracia ou poliarquia (WGS empregava os termos como sinônimos) era um regime específico que, para existir, exigia oito condições: liberdade de pensamento e associação; liberdade de expressão; direito de voto; elegibilidade para os cargos públicos; competição política; pluralismo de informação; eleições livres e periódicas; e instituições representativas. Ocorre que, embora a democracia exigisse a participação de todos, os recursos políticos de conhecimentos, 
habilidades e incentivos eram sempre desigualmente distribuídos. Enquanto os custos de repressão excedessem os custos de tolerância aos adversários, as chances de sucesso democrático se mantinham. Caso a desigualdade tocasse um grau crítico, ela poderia comprometer a democracia. Dahl também explicava a origem dos regimes democráticos. Partindo originalmente de um regime autocrático ("hegemonia fechada"), a democracia resultara de um processo de desenvolvimento político caracterizado por dois fenômenos. O primeiro havia sido a institucionalização das regras e mecanismos de resolução dos conflitos políticos, através da consagração do princípio das garantias mútuas ("eixo da institucionalização"). O segundo fenômeno teria sido o crescimento da participação e da competição políticas ("eixo da participação"). Havia ainda dois itinerários básicos para se chegar à poliarquia: ou pelo alargamento de um sistema representativo oligárquico, ou pela incorporação da participação política no quadro de um regime autoritário ("hegemonia inclusiva"). Como se passava com Olson, WGS identificaria insuficiências na teoria de Dahl e contribuiria para supri-las em artigos como Poliarquia em 3D (1998). Primeiramente, desenvolveu o conceito de sistema representativo oligárquico, entendido como um regime distinto do democrático, que exigia teorização à parte. Posteriormente, passou a sustentar que, além dos eixos de institucionalização e da participação, haveria um terceiro a ser levado em conta no desenvolvimento poliárquico: aquele do controle da elegibilidade dos candidatos. Quanto menor o controle de quem pudesse se candidatar por parte do regime político, mais democrático ele seria (Santos, 1998a:10).

\section{TEORIA DA MUDANÇA POLÍTICA: TIPOLOGIA DE REGIMES, REFORMA E RUPTURA}

\section{Da crítica do desenvolvimentismo às teorias do desenvolvimento político}

Os intelectuais do ISEB em sua primeira fase de existência haviam defendido a ideologia do nacional-desenvolvimentismo na suposição de que a industrialização da economia traria de modo mais ou menos automático a modernização social e política do país. WGS criticaria essa tese de seus antigos colegas em livros como Reforma contra reforma (1963a) e Introdução ao estudo das contradições sociais no Brasil (1963b). Neles, o jovem isebiano alegava que a mobilização e a radicalização gerada pelo desenvolvimento socioeconômico, no contexto de uma democracia limitada, poderia resultar também 
na instalação de um regime autoritário. Eram as necessidades de expansão do capitalismo no Brasil que levavam direita e esquerda a divergirem sobre as reformas de base (Santos, 1963a:10). Como é sabido, o colapso do regime liberal democrático em 1964 levou a intelectualidade a substituir a ideologia nacional-desenvolvimentista por uma sociologia do desenvolvimento ancorada na ideia de dependência do capitalismo dos países periféricos em relação às economias centrais do planeta. Além disso, o elevado crescimento econômico promovido pela política do regime militar (o "milagre"), no começo da década de 1970, desmentia o economicismo de marxistas e cepalinos, para os quais a esfera política apenas espelhava a econômica. O crescimento econômico é que havia sido produto de uma escolha política do regime militar (Lynch, 2017). Outra mudança foi a drástica renovação da bibliografia sobre ciência política, decorrente da nova influência americana. A antiga livraria francesa de filosofia existencialista, de tintas germânicas e marxistas, foi posta de lado em proveito de autores como David Easton, Karl Deutsch, David Apter, Samuel Huntington e Sidney Verba. Foi a partir desses novos referenciais que a primeira geração de cientistas políticos brasileiros "profissionais" passou a refletir sobre os problemas do desenvolvimento político, um dos temas mais candentes da academia naquela época. No curso de seu doutorado em Stanford, WGS participou do famoso grupo de política comparada de Gabriel Almond, que instruía seus alunos oriundos do Terceiro Mundo a escreverem sobre as dificuldades de trânsito do autoritarismo para a democracia em seus pobres países de origem.

Em Explicação e predição de desenvolvimento político (1971), trabalho de final daquele curso, WGS comentava criticamente quase todas as obras a respeito escritas por seus professores, a começar pelo próprio Almond, e por colegas como Lucien Pye, Frederick Frey e Edward Shils. Já então ele demonstrava seu incômodo com o que havia de rudimentar nesses trabalhos, que lhe pareciam marcados pela falta de consenso quanto a conceitos fundamentais como democracia, autoritarismo e ditadura, e de clareza a respeito das condições capazes de explicar a mudança política. Este incômodo se estendia à teleologia das teorias da modernização, marcadas por uma sequência obrigatória de etapas de viés eurocêntrico: era a imagem das sociedades avançadas que servia de norte às teorias do desenvolvimento político (Santos, 1971:72-74). As análises do processo de construção estatal nos países periféricos elaboradas pelos alunos de Almond 
reproduziam implicitamente juízos de valor que tinham quase sempre por referência positiva as instituições norte-americanas, britânicas ou escandinavas. Na maturidade, WGS atenuaria suas próprias críticas: tais estudos seriam pioneiros na tentativa de compreender a mudança política, "ousando hipóteses de conexões históricas suscetíveis de argumentação factual" (Santos, 2017a:59). Ele também criticaria a vasta literatura sobre o trânsito do autoritarismo à democracia, organizada pelo cientista político espanhol Juan Linz, como mera "etiquetologia". Tipologias, para serem úteis, deveriam ser exaustivas e apresentar tipos mutuamente excludentes, o que não era o caso daquelas elaboradas por Linz. Embora cada país fosse autoritário à sua maneira, o excesso de cuidado em não perder de vista o que neles havia de especial o levara e a seus associados a perder de vista o que havia de comum em todos. Por mais importantes que fossem os acidentes de cada país, o que interessava ao cientista político eram as similaridades entre as experiências transnacionais ${ }^{9}$. Essas críticas o levariam a buscar um caminho diferente para pensar o processo de mudança política. E, aqui, foi Robert Dahl quem indicou o caminho a seguir.

\section{Teoria da mudança política: nem eurocêntrica, nem teleológica}

A observação rigorosa dos processos históricos de democratização dos países desenvolvidos demonstrava mais analogias com os dos periféricos do que supunha a vasta literatura de viés eurocêntrico em curso desde a década de 1950. Em diversas democracias consideradas exemplares, como a França, a poliarquia não teria surgido do "bom caminho" do alargamento de regimes oligárquicos, mas de regimes autoritários de tipo bonapartista - aqueles chamados por Dahl de "hegemonias inclusivas". O fenômeno confirmava o papel da contingência no desenvolvimento de cada país: "O trânsito entre autoritarismo, oligarquia e poliarquia é algo mais complexo do que vãs filosofia ou poética supõem" (Santos, 1998a:16). A democracia não era um bem conquistado de uma vez para todo o sempre. Como qualquer arranjo humano, ela estava sujeita à mudança, por ampliação ou retrocesso, inclusive em países supostamente modelares, como os Estados Unidos e a Grã-Bretanha:

O caráter insondável do futuro não inspira assaz confiança para que se afaste completamente a hipótese de que, por caminhos inéditos, surtos autoritários venham a acometer os países ricos e de enraizadas tradições democráticas (Santos, 2007:14). 
Os dados sobre o processo de democratização, em perspectiva histórica comparada, desmentiam as teses consagradas pela literatura. Em primeiro lugar, a associação entre formas de governo e sistemas de representação variava tanto no agregado dos países democráticos quanto na história singular de cada um. Em segundo, o número de nações que mudavam de configuração institucional não revelava padrão sistemático. Em terceiro lugar, os trajetos de ida e volta também não apresentava regularidade: "Assim como se pode chegar ao autoritarismo a partir de qualquer tipo de democracia, a qualquer uma delas se pode também voltar" (Santos, 1998b:18). Por fim, a estabilidade democrática não encontrava sua condição necessária ou suficiente em nenhuma associação institucional específica. Tudo pesado, WGS apostava em um modelo explicativo da mudança política, que envolvia três tipos ideais de regime, com as cautelas de estilo: "Todo modelo de funcionamento de uma ordem social dada implica certa simplificação e certo grau e idealização do que efetivamente se passa na empiria" (Santos, 1985:289).

\section{Tipologia de regimes políticos (1): a autocracia ou autoritarismo}

Em Autoritarismo, capitalismo e socialismo (1975), WGS argumentava que a estabilização de toda ordem dependia da redução da imprevisibilidade do comportamento social. O regime democrático se desincumbia dessa tarefa regulando pouco a vida dos cidadãos, porque eles seriam socializados a partir dos valores liberais incutidos pelas instituições. Os regimes autoritários, ao contrário, buscavam reduzir o imprevisto social pelo emprego sistemático da coação, tendendo por isso ao furor regulatório. Era o uso autoritário do poder que tornava autoritárias as instituições, na medida em que as empregava para aniquilar qualquer tipo de oposição. A autocracia não comportava participação nem competição verdadeiras. Se a democracia reconhecia o direito que tinha a oposição de suscitar dúvidas legítimas sobre o acerto das decisões do governo, a autocracia partia da certeza totalitária de que ela só desejava empalmar o poder a fim de exercê-lo contra si, e de modo ainda mais autoritário. Mas WGS sugeria que o emprego sistemático da coação era antes indício de fraqueza do que de força. Em Poder e política (1977), afirmava que, porque assentados na força e na expectativa de obediência automática, os regimes autoritários eram instáveis. A ausência de uma oposição clara produzia um antagonismo difuso e, por conseguinte, uma permanente ameaça da irrupção contestatária. O resultado era uma tensão circular entre autoritarismo e paranoia: 
O exercício do puro poder se autojustifica pela necessidade de defesa contra os radicalismos salvacionistas, enquanto as providências tomadas para reprimi-los são elas próprias ativadoras de messianismos conspiratórios (Santos, 1977:31).

Era a própria dinâmica do regime autoritário que o impedia, afinal, de estabilizar-se: ou ele crescia indefinidamente para absorver cada vez mais a totalidade da vida comunitária, ou definhava, permitindo que outros poderes controlassem os novos focos de poder. Daí que, cedo ou tarde, todos os regimes autoritários se defrontassem com o dilema de terem de reprimir cada vez mais ou se liberalizarem de vez. Devido à sua incapacidade de se manter numa espiral permanente de coação, os regimes autoritários acabavam suscetíveis a processos de abertura política.

A respeito da transição do autoritarismo ao sistema representativo, WGS argumentava, em $O$ século de Michels, que o problema da participação se punha sempre que rompida a correlação entre posição social e posição política; ou seja, "quando o lugar de alguém na pólis deixa de estar automaticamente assegurado pelo lugar que esse mesmo alguém ocupa no demos" (Santos, 1985:286). Quando os interesses sociais deixavam de encontrar representação junto ao governo, ficando o demos (a sociedade) mais amplo do que a pólis (o governo), as posições no sistema político começavam a ser objeto de competição. A transição da autocracia para o sistema representativo ocorreria, assim, para restabelecer a efetiva representatividade ao exercício do poder entendida a representação adequada como critério de sua legitimidade pela opinião pública. Os excluídos da representação deflagravam um processo duplo: por um lado, pressionavam pela ampliação dos direitos de participação referentes ao sufrágio; de outro, pela quebra do monopólio dos cargos públicos detido pelo estamento aristocrático. Ao mesmo tempo, o crescimento econômico levava à constituição de uma sociedade de mercado que substituía a ordem patriarcal e agrícola por mecanismos de mediação econômica e novas estruturas sociais:

A ampliação da polis se fez, pois, duplamente: de um lado, pelo movimento de fazer coincidir a sociedade política com a sociedade stricto sensu, derrubando-se as barreiras à participação política; de outro, pelo movimento de incorporar à pólis, isto é, à sociedade política organizada sob o controle do demos, um número cada vez maior de funções do governo, que deixavam, deste modo, de ser monopólio adstrito os bemsucedidos, os delegados do rei ou dos notáveis em geral, e passavam 
a fazer parte dos objetos de competição. É este processo simultâneo de expansão burguesa e dos assalariados que nacionaliza a competição política, ao mesmo tempo em que se vão delineando as instituições que exprimiriam as novas formas de conflito (Santos, 1985:289).

A ciência política moderna já podia esboçar uma estratégia geral de abertura ou liberalização do sistema autoritário. Uma política de descompressão deveria apresentar um aspecto incremental, modificando a estrutura do regime autoritário por aproximações sucessivas e modificações marginais. A estratégia passava menos por maximizar a velocidade da descompressão do que por minimizar os riscos da recompressão. Para isso, cumpria evitar a simultaneidade das pressões, absorvendo-as uma a uma. Era um modo mais simples de formar coalizões de apoio às decisões tomadas, porque elas se organizavam em torno de consensos específicos. Impunha-se, igualmente, evitar a cumulação dos desafios. Ao renunciar aos instrumentos gerais de coação ou de repressão, o regime autoritário precisava substituí-los por outros, específicos, que obrigassem as áreas liberadas a não extravasarem os limites da descompressão planejada. A estratégia exigia também processos compensatórios, que aumentassem a possibilidade de adesão leal dos insatisfeitos ao sistema. Só assim se rompia, pouco a pouco, o monopólio do poder sobre o processo decisório. Era preciso igualmente identificar as áreas a serem prioritariamente descomprimidas: restauração da inamovibilidade do Poder Judiciário; da liberdade de opinião e divulgação do pensamento; das garantias individuais; da liberdade de expressão e de reunião; dos direitos políticos; e do devido processo legal (Santos, 1977:153-160).

\section{Tipologia de regimes políticos (2): a oligarquia representativa}

Os sistemas representativos são definidos por WGS como "complexos combinatórios de quatro atributos de direito: expressão, organização, votar e ser votado, conforme estejam institucionalizados segundo o princípio das garantias mútuas" (Santos, 1998b:10). Haveria dois tipos de sistemas representativos, o oligárquico e o democrático. Os sistemas oligárquicos eram

(...) aqueles em que nenhum membro (que pode ser uma coletividade de pequeno porte) ou reduzido grupo deles é capaz de produzir um bem coletivo, ainda que o deseje, sem a cooperação de todos os demais; em 
contraste, pequeno subgrupo de oligarcas, um somente, no limite, é capaz de impedir a produção do bem, não obstante a cooperação de todos os demais (Santos, 1998a:25).

A estabilidade repousava no acordo unânime dos oligarcas sobre quem deveria estar excluído da representação e da participação, exclusão assegurada por diversos requisitos eleitorais referentes à renda, idade, condição civil, educação, sexo, religião e raça dos eleitores e dos candidatos. As próprias eleições eram viciadas mediante fraude como garantia adicional daquela mesma exclusão. Com o escasso eleitorado e a representação homogênea, o Estado podia se reduzir ao mínimo e ser indiferente a demandas coletivas. Do ponto de vista ideológico, oligarquias representativas eram regimes conservadores, dominados por elites rurais de ressaibos aristocráticos, que duvidavam de sua capacidade de adaptação empresarial. Dada a inexistência de um exército profissional, o poder coercitivo era exercido pelas milícias dos grandes proprietários de terras. A psicologia conformista das classes subalternas se exauria quase sempre no sentimento de inveja ou pretenso desdém. Sociedades de temporalidade lenta, eis que ancoradas na propriedade fundiária, as oligarquias eram capazes de reprimir as revoltas dos excluídos com um grau invejável de eficiência. Esses conflitos eram resolvidos pelo emprego da violência física localizada, a fim de manter restrita e estável a competição no âmbito maior do sistema oligárquico.

Quanto à transição da oligarquia representativa à democracia, WGS afirmava que o regime oligárquico entrava em crise devido ao seu próprio êxito em promover o crescimento econômico. O processo de industrialização o condenava à morte:

A expansão econômica via oligárquica representa, em verdade, uma programação para a morte que não pode ser cancelada, exceto por retrocesso a alguma forma de autocracia. O limite da capacidade extrativa do governo central, via impostos, limite estabelecido pela facilidade oligarca de produzir desordem, obriga a expansão da base a ser taxada, o que equivale a favorecer a expansão dos negócios (Santos, 1998a:26).

Era o fantasma da competição que rondava a oligarquia: o fim da sociedade agrária e a urbanização tornavam a divisão do trabalho mais complexa e multiplicava os aspirantes a ingressar no sistema político. Em Da oligarquia à poliarquia (1997), WGS explicava que a competi- 
ção se relacionava a quatro processos: competição por partidos, entre eleitores, entre partidos e entre os candidatos, independentemente de filiação. Enquanto os conflitos decorrentes da transformação na infraestrutura social exigiam a modernização institucional, conter a pressão pela derrubada das barreiras à participação requeria crescente violência institucionalizada da oligarquia. O fenômeno se multiplicava por todas as jurisdições oligárquicas, levando à multiplicação das desordens locais simultâneas e contaminando o horizonte de expectativas. Emergiriam conflitos entre as oligarquias, dividindo-as acerca das providências a serem tomadas: ou alargar a participação, aumentando o eleitorado no rumo da democracia, ou violar as regras institucionais do jogo, forçando o retorno à autocracia. Quando as pressões alargavam o sistema de modo a universalizar o voto, elevar o comparecimento eleitoral e generalizar eleições competitivas, os sistemas oligárquicos começavam a se tornar democráticos (Santos, 2017a:81-96).

\section{Tipologia de regime político (3): a poliarquia ou democracia representativa}

A democracia (ou poliarquia) era um regime generalizado na segunda metade do século 20, junto ao número de países industrializados, que multiplicavam os interesses a representar. Associada à universalização do voto e à difusão da igualdade de direitos, a democracia era um regime de instabilidade produtiva. Ela permitia transformações sem rupturas, promovidas pela hegemonia da economia de mercado enquanto método principal de alocação de bens e valores. A poliarquia apresentava duas características mínimas: primeiro, a competição eleitoral a intervalos regulares, com regras explícitas e resultados reconhecidos pelos competidores; segundo, a participação mediante um sufrágio universal, cuja única barreira fosse o requisito de idade: "Naqueles países que praticam eleições regulares, quanto mais restrita for a competição, mais oligárquico será o sistema. Inversamente, quanto mais regular, legalmente organizado e respeitada a competição, mais poliárquico o regime" (Santos, 2007a:39). O regime de liberdade e participação favoreciam a mobilidade social e a contínua inovação institucional e produtiva, própria das sociedades capitalistas complexas. $\mathrm{O}$ conflito se processava dentro de limites razoavelmente seguros, de forma a favorecer a integração, a criatividade e a inovação por parte dos indivíduos, sem as quais não teriam como se realizarem como pessoas. Mas não era só a liberdade que saía ganhando. Na medida em que as eleições passavam a espelhar os conflitos distributivos, elas também 
podiam gerar ganhos para as classes menos favorecidas, em contraposição à "estilizada e estéril estabilidade das oligarquias" (Santos, 2017a:71). O eleitor médio votava na democracia com o intuito de melhorar sua situação na estrutura de oportunidades sociais, e o sistema de crenças ideológicas assumia um papel eminente na mobilização. A igualdade de condições tornava-se o horizonte das classes subalternas, que passavam a crer na aquisição de bens antes inacessíveis. A democracia, deixada naturalmente à sua própria dinâmica, proporcionava assim um contínuo alargamento da liberdade e da igualdade cidadãs.

\section{Gradualismo como método natural de reforma política}

Instituições resultavam da sedimentação de conflitos, estratégias e invenções que, reunidas, produziam uma configuração específica em cada sociedade. Não havia modelo definido de boa representação, dedutível abstratamente de princípios e universalmente aplicável. Por esse motivo, WGS condenava a "tentação demiúrgica" de engenheiros de instituições. Em Regresso: máscaras institucionais do liberalismo oligárquico (1994), ele sugeria, na esteira de Hume e Burke, que o efeito real das instituições recém-introduzidas raramente correspondia às intenções dos legisladores. A necessária cautela decorria da indeterminação social provocada pela "mão invisível do caos". Uma vez que a trama societária era o mais precário coeficiente técnico conhecido, a taxa de imprevisibilidade da inovação abstrata era enorme. A instituição transplantada sofria transmutações, tornando imprevisível a configuração resultante. Nada assegurava que, do mesmo estoque e composição de insumos (leis, instituições), corresponderiam os mesmos "produtos" (comportamentos, respostas sociais, preferências políticasetc.). Em Governabilidadeedemocracianatural (2007), WGS sugeria que a melhor garantia da governabilidade nesse regime era a prática da "democracia natural" (Santos, 2007a: 16 e 150). Somente mudanças lentas e graduais como resultados de acordos pontuais poderiam compatibilizar inovação e estabilidade. Havia uma única fórmula da reforma natural em uma democracia: "Experimentar inovações institucionais e, ao mesmo tempo, orientar com cautela a sequência e a velocidade de sua adoção" (Santos, 1994:19). Wanderley não advogava uma mumificação institucional, mas desejava alertar "para a frivolidade com que são tratadas questões institucionais de microscópica e fractal sensibilidade" (Santos, 1994:19). Todos os transplantes institucionais que desprezassem as configurações culturais de cada democracia mereciam condenação: 
Nenhuma sociedade, é certo, vive sem imitações, mas estas nunca funcionarão como os originais. Instituições evoluem adaptando-se a problemas, correntes e contracorrentes reais, não por silogismos doutrinários. Reformistas doutrinários, contudo, acreditam piamente que transplantes institucionais não acarretam custos e que, ademais, os benefícios esperados, tendo em vista a experiência estrangeira, são favas contadas. Estes são dois enormes equívocos quanto à história institucional de qualquer povo sobre a terra. Ainda mais, escapa-lhes este grão fundamental de sabedoria histórica: enquanto não existe exemplo de sociedade avançada e estável que seja mero resultado de uma coleção de transplantes, todos os países institucionalmente subdesenvolvidos e instáveis carregam o estigma recorrente do mimetismo institucional. É porque a eficácia das instituições não é invariante em relação às demais instituições, nem à ecologia social sobre que se assenta, que a utopia do transplante costuma converter-se em delírios experimentais, às vezes irresponsáveis (Santos, 1993b:108).

\section{Ruptura democrática: os golpes de Estado}

Golpes eram definidos por WGS como "rupturas do contrato social que teórica e preliminarmente obriga seus participantes a preservarem o contrário constitucional posterior" (Santos, 1994:66). A vida democrática não estava resguardada contra interrupções, recuos e retrocessos. Quando a competição pelos recursos escassos de poder, status e riqueza ou bem-estar material resultava em um jogo de soma zero, em que o ganho absoluto de um grupo implicasse a perda absoluta do outro, abriam-se as portas para o "assalto ao poder, espasmos revolucionários, golpes de Estado, enfim, o uso generalizado da violência como recurso político predominante" (Santos, 1978:55). Sua ocorrência pressupunha falta de fé no "contrato social", isto é, o conjunto de regras básicas que assegurava a convivência democrática. Os contrariados estavam dispostos a violá-lo sempre que a medida lhes parecesse indispensável à preservação de seus interesses. Teoricamente, os golpes podiam ser desfechados pela esquerda ou pela direita. Os envolvidos seguiam a lógica do "atentado preventivo", encaminhando-se a velocidades diferentes para a posição do golpe, executando-o antes que o outro o fizesse. Na prática, o "golpe de esquerda" era geralmente promovido pela ala progressista das elites contra a mais conservadora, e tinha por isso fôlego curto. Os setores conservadores eram, assim, responsáveis pela maioria esmagadora dos golpes. A gradual implantação dos valores políticos do liberalismo assustava os detentores do capital e as classes médias: "Com frequência, grupos recém-incorporados às fran- 
quias democráticas tentam obstruir o ingresso dos ainda civicamente incapacitados, comportando-se às vezes como ferozes síndicos da exclusão" (Santos, 2007b:16). O golpismo não decorria, portanto, da saudade de oligarquias ou de ditadores, mas da surpresa provocada pela prática relativamente universal das regras democráticas.

Haveria, então, dois gêneros de golpes de Estado. O primeiro era o clássico ou autoritário, caracterizado pelo rompimento violento e explícito com as regras que pactuavam a ordem política. Diante das pressões pela ampliação da participação e da competição, os golpes autoritários visavam a interromper ou sobrestar a transição dos regimes oligárquicos para os democráticos. Em Quem dará o golpe no Brasil? (1963b), o golpe militar era definido por WGS pelo domínio direto e pessoal do aparelho do Estado pelos dirigentes das Forças Armadas. Mas o golpe podia também ser promovido para instalar um governo forte, descrito retoricamente por seus defensores como "um governo acima dos partidos, com autoridade suficiente para impor, contra a vontade dos partidos, se necessário, aquelas medidas que consultem aos verdadeiros interesses de segurança e salvação nacionais" (Santos, 1988b:122-123). A narrativa da mecânica dos golpes é acompanhada na obra de WGS por uma lição de moderação. Embora sempre louvasse a dimensão criadora do conflito, havia um ponto a partir do qual ele se tornava nocivo, contaminava o consenso mínimo de que dependia a democracia:

O problema da lealdade não está tanto ligado ao desaparecimento do conflito, mas sim à responsabilidade na participação de formas de convivência política que admitam a existência do conflito com base numa pauta de consenso mínimo, sem o que a sociedade realmente não sobrevive (Santos, 1977:174).

Convinha em situações críticas, portanto, adotar soluções de compromisso, inclusive em matéria de justiça distributiva: "A radicalização doutrinária, creio, é um mau caminho para se atingir a meta do desenvolvimento social. [...]. Políticos e cidadãos aprendem através da experiência" (Santos, 1986:137). Em seu artigo Autoritarismo e após: convergências e divergências entre o Brasil e o Chile (1982), WGS fornecia uma receita para coibir o enredo golpista: 
a) evitar ser apanhado pela lógica de uma ideologia que não aceita solução alternativa à solução ótima; b) evitar a armadilha do processo de exasperação política; c) preservar algum espaço para negociações com uma oposição leal; d) não tentar atingir um poder de decisão monopolista (Santos, 1982:157).

Quanto mais a democracia se enraizava, mais as formas tradicionais de autocracia se tornavam de difícil implantação. Razão pela qual teriam emergido modalidades mais novas e sutis de restrição do poder popular, de tendência oligárquica. Elas se caracterizam, hoje, menos por oporem obstáculos à participação, do que por estreitar a competição eleitoral, reprimindo a oferta de candidatos a pretexto de garantir a governabilidade ou a boa qualidade da política (Santos, 2007a:41). Aqui reaparece a ideia, exposta primeiramente em Poder e política (1978), segundo a qual o respeito às instituições não se esgotava na observância das formalidades jurídicas. A estabilidade democrática repousava em um "contrato social" baseado na boa-fé dos membros da comunidade política:

O que o desenrolar da história tem revelado é que o funcionamento das instituições depende da alma que as habita, quer dizer, do pacto que lhes dá sentido e que as torna eficientes e efetivas ou meros simulacros. O simples formalismo da lei, por mais elegante que seja, é insuficiente para tornar compatível o que permanece em disputa na prática política cotidiana. Instituições só instrumentalizam soluções quando essas já foram aceitadas pelos atores envolvidos. Enquanto isso, vale o truísmo de que os problemas políticos requerem soluções e ações políticas (Santos, 1978:51).

Então, era possível que as instituições fossem golpeadas em seu espírito, sem necessariamente atingirem o texto formal da lei. Tratava-se de um segundo gênero de golpe de Estado, mais consentâneo com a democracia contemporânea: o golpe branco - ou legal -, que não recorria à violência explícita, sequestrando a vontade do povo preservando as aparências legais.

Golpes brancos ou legais eram, assim, próprios das democracias contemporâneas e comportavam duas espécies. A primeira vinha encapuzada em propostas de reformas políticas voltadas à restrição da participação e da competição. Conforme sugerido em Regresso (1994), as oligarquias ameaçadas pela participação e pela competição propunham o sistema eleitoral majoritário ou distrital e cláusulas de desempenho aos partidos menores, a pretexto de restaurar a governabilidade, a ética e a re- 
presentatividade, que estariam comprometidas pela massificação. Mas WGS advertia que semelhantes instituições não ofereciam garantias de estabilidade, não eram mais modernas, nem diminuíam os custos da competição; e menos ainda a ineficiência parlamentar. Eram, na verdade, mecanismos arcaicos e decadentes, que violavam os princípios de justiça alocativa e distributiva para cristalizar oligarquias partidárias ameaçadas. Conforme WGS reiterava em 1994, não era a legislação nova que tornava um sistema político menos vulnerável aos males da competição, mas "o espírito da lei, sua alma; aquilo que faz com que a maioria dos cidadãos a ela se conforme, não por temor das punições, mas por adesão convicta" (Santos, 1994:40). Já a segunda espécie era o golpe parlamentar, que violava o princípio de que, para promover a substituição fraudulenta de governantes, obrigava os derrotados a aceitarem os resultados eleitorais. Em A democracia impedida (2017), WGS explicava que os golpes parlamentares tentam

(...) preservar o efeito-legalidade das instituições, a normalidade rotineira das operações, enquanto altera hierarquia das preferências governamentais, substituindo o luzeiro teleológico, a finalidade que, alegadamente, preside as decisões subversivas (Santos, 2017a:12-13).

O jogo democrático da negociação se transformava em um chicken game, em que o sorrateiro movimento de um jogador colocava o outro em uma situação paralisante. O grupo deposto, tornado oposição, não tinha alternativa de contra-ataque legítimo. Caso se recusasse a jogar, facilitava as manobras do governo usurpador; e se colaborasse, reconhecia sua legitimidade. Os golpes parlamentares, WGS acreditava, estavam se tornando regra nas democracias contemporâneas.

\section{A DEMOCRACIA EM TRÊS DIMENSÕES: INTEGRAÇÃO, PARTICIPAÇÃO E REDISTRIBUIÇÃO}

Democracia sob o ângulo da integração social: a divisão do trabalho nas sociedades industriais

Compreendida a democracia a partir de uma concepção dinâmica da mudança política, WGS passava então a considerá-la de um ponto de vista mais estático. Baseado em Sequências e desenvolvimento, de Sidney Verba, sustentava que toda ordem estável dependia da resolução periódica de crises de integração social, de participação política 
e de redistribuição de recursos (Santos, 1993c:17). Do ponto de vista da integração social, as ordens políticas - autocrática, oligárquica e democrática - encontravam correspondência em certos modos de organização socioeconômica: o agrícola, o comercial e o industrial. Cada qual apresentava especificidades relativas às suas bases materiais, às suas redes de solidariedade e formas de ação coletiva. Era, como se pode perceber, um esquema interpretativo na longa duração, a que ele, como ex-marxista, aludia ironicamente como "o meu materialismo". A integração exigia a constituição de um Estado robusto e independente como condição de uma sociedade de mercado em escala nacional. Esta seria complementada por instituições que assegurassem a participação e os direitos civis da população em todo o seu território. Para WGS, qualquer processo de integração exigia fórmulas de acento nacionalista, sobretudo em um país periférico. Do contrário, ele não se afirmaria de modo verdadeiramente livre na ordem internacional (Lynch, 2013). O nacionalismo, ainda que moderado, facilitava a centralização do poder, o combate aos poderes periféricos, a imposição da autoridade do governo nacional, a disseminação do aparelho administrativo e o acesso à Justiça. Em tal esquema arquetípico, a democracia surgia em segundo momento, como produto das complexas relações instaladas pela divisão do trabalho própria à sociedade industrial. No plano da participação, a industrialização convertia as antigas oligarquias representativas em democracias; no plano da redistribuição, a sociedade industrial substituía o Estado mínimo ou absenteísta por outro, de orientação intervencionista: "A sociedade industrial é mais do que uma sociedade, é uma civilização em todos os aspectos políticos, materiais, culturais, sociais" (Santos, 2019b:27). A sociedade industrial impactava profundamente, por conseguinte, sobre a forma de organização do Estado nacional, da integração territorial e da participação política:

A estabilidade das fronteiras nacionais e a gradativa universalização dos direitos de voto aparecem como especiais condicionantes uma da outra. A expansão dos direitos alcançava segmentos populacionais localizados, além de informar os limites do território, incorporando, pela via política, novas faixas do terreno. [...]. A redução das lealdades locais exige tempo e prática em todos países, e o voto compulsório foi um dos instrumentos eventualmente utilizados para levar a participação e a lealdade ao Estado nacional (Santos, 2018:56). 


\section{Democracia sob o ângulo da participação política (1): a defesa da democracia liberal}

Em O paradoxo de Rousseau (2007), WGS rejeitava concepções substantivas de democracia, isto é, que acreditavam na unanimidade de decisões coletivas, fosse pelo recurso à participação direta e/ou plebiscitária: "A tese da democracia permanente, para qualquer político que haja ultrapassado a juventude, não se desvencilha de sua antepassada siamesa histórica, a tese da revolução permanente" (Santos, 2007a:26). Plebiscitos massacravam o pluralismo, supondo unanimidade em maiorias ocasionais, sem oferecer garantia de uma boa decisão. A concepção de democracia à lá Rousseau condenava irrealisticamente o interesse particular como incompatível com o público, apostando na abnegação ou altruísmo dos cidadãos. Ela exigia dos cidadãos que, enquanto membros do corpo soberano na esfera pública, quisessem aquilo que eles próprios rejeitariam como súditos, na esfera privada. A democracia substantiva, plebiscitária ou direta, só poderia ser um fracasso de ação coletiva. Ao ideal irrealista de unanimidade, à maneira de Hume, WGS preferia um "modesto mundo infra-iluminista" de inspiração moderadamente cética, por ele qualificado como o "péssimo de Rousseau". Em semelhante mundo, o interesse de todos poderia ser atendido mesmo na ausência da unanimidade, e haveria sempre a possibilidade de uma participação de todos sem coação nem abnegação, voltada à satisfação de seus próprios interesses. Era uma democracia na qual, ao contrário do que imaginava a imutável metafísica rousseauniana, vigorava uma verdadeira história, cuja materialidade possuía tanto um poder causal ontológico, demiúrgico e criativo, quanto o de dissolução de conexões pretéritas entre fenômenos cotidianos. Com amplo sufrágio e competição, operando por meio de instituições, a democracia representativa era o regime que melhor articulava mudança com legitimidade e criatividade inovadora com estabilidade:

Em assuntos humanos, nunca é possível fazer apenas mais do mesmo. Assim como adição de um a um se converte em dois ou 11, a reiterada execução dos mesmos gestos e rituais transforma lentamente, para subitamente explodir, o mesmo em outro. Até porque só em aparência o mesmo é o mesmo [...]. Entender o mundo de maneira evolutiva, como anteriormente estipulado, obriga a aceitar a caducidade dos sistemas causais e a substituição de processos constitutivos - não somente a rotatividade dos croupiers e apostadores à mesa do mesmo enredo de probabilidades (Santos, 2007a:127 e 130). 
Em outras palavras, WGS era um adepto convicto da democracia liberal, entendida como um regime caracterizado pelo mais amplo sufrágio e concorrência de candidatos ("democracia"), e sistemática mediação institucional dos conflitos sociais ("liberal"). Ele acrescentava que a poliarquia era a única forma de exercício do poder que reconhecia como legítimas demandas que não podia atender. Cuidava-se de um governo inédito, que equilibrava liberdade individual e soberania pública, conciliando a autonomia dos indivíduos com a imprevisibilidade do modo de produção econômica. Uma vez continuada, a democracia trazia os determinantes de sua própria transformação, apresentando, em seu estado de permanente inconclusão, sua característica essencial. Em um mundo marcado pela radical ignorância a respeito do mundo social e no qual a mudança era o resultado agregado imprevisível de microprocessos, a democracia deveria evoluir de forma endógena para sobreviver. Nesta qualidade, a "democracia natural" representava o mais formidável desafio jamais oposto às pretensões oligárquicas "de geométrica dominação hierárquica" (Santos, 2007a:151).

\section{Democracia sob o ângulo da participação política (2): a defesa das instituições representativas}

As instituições políticas estavam longe de ser epifenômenos de tendências macrossociais e macroeconômicas. Mereciam ser estudadas como variáveis independentes, que se relacionavam de uma maneira dupla com os processos sociais: "De um lado, definem a maneira pela qual as formas de competição social e econômica se traduzem em alternativas de políticas; de outro, produzem impacto sobre o desenvolvimento ulterior da estrutura social"' (Santos, 1986:21). Não era pouca coisa. Uma vez que eram as instituições que filtravam os conflitos sociais e econômicos, da sua escolha dependia o desenvolvimento geral de um país. Se a qualidade da democracia dependia da qualidade das instituições, a primeira função de um bom sistema eleitoral e partidário era o de preencher os requisitos essenciais de autenticidade e representatividade. Por autenticidade, entende-se aqui o vínculo entre eleitores e eleitos, que levava os segundos a serem percebidos como representantes legítimos dos primeiros; por representatividade, entende-se, por seu turno, "o grau de correspondência entre a distribuição de preferências partidárias entre os eleitores e a distribuição de poder parlamentar entre os partidos" (Santos, 1987:37). Os partidos eram os principais veículos de representação dos interesses, sem os quais 
o sistema representativo era impossível. Sua alternância no poder se processava em ciclos semelhantes ao econômico: “Um partido perde a eleição, não importa o que faça, na dependência do tempo em que tenha ocupado o poder. Ou seja, um partido perde o poder simplesmente porque estava no poder" (Santos, 2007a:79). Mas a decadência democrática também era possível, desde que as funções públicas fossem capturadas por tecnocracias irresponsáveis; e se multiplicassem identidades coletivas fora do sistema partidário, em decorrência do processo de divisão do trabalho. Para sobreviver, a "democracia natural" não tinha outra opção, senão ampliar continuamente suas formas de representação, sem jamais restringi-las (Santos, 1985:292). Advogando a superioridade democrática da teoria da representação proporcional desenvolvida por José de Alencar sobre as de Madison, Stuart Mill e Tocqueville, WGS a resumia em cinco pontos essenciais:

1. Quanto mais denso o mandato, mais democrático; 2. Quanto mais proporcional, mais democrático; 3. Quanto maior a participação eleitoral, maior a extensão em que o governo é de todos por todos; 4. Quanto mais obedecer à regra fundamental de não tirania da maioria e não poder de veto da minoria, mais democrático; 5 . Quanto menor o prazo e o escopo do governo, mais democrático (Santos, 1987:27).

Orientado por esses cinco critérios extraídos da teoria de Alencar, WGS defendia a superioridade em matéria democrática de determinadas instituições políticas, tais como o sistema eleitoral proporcional de lista aberta; a possibilidade de candidatura avulsa e a irrestrita pluralidade partidária. Seus críticos, ao contrário, desconheciam a natureza do regime democrático:

Os cuidados contemporâneos com problemas de capacidade governativa decorrem da disseminação da ordem democrática, antes que do esgotamento desta. Precisamente porque não se conheciam as consequências do funcionamento rotineiro de reais democracias, suas condições normais de operação costumam provocar apreensões, confundindo-se a normalidade funcional com sintomas de patologias (Santos, 2007a:77) ${ }^{10}$.

Em Governabilidade e democracia natural (2007), WGS defendia o sistema partidário proporcional de lista aberta, os partidos "nanicos" e a inexistência de cláusula de barreira. Ele afirmava, em primeiro lugar, que a distribuição de cadeiras do Parlamento dependia da dis- 
tribuição de preferência do eleitorado, não havendo simetria entre a importância eleitoral de um partido e sua relevância parlamentar. Em segundo lugar, os determinantes da atividade de um partido representado no Legislativo dependiam principalmente da estrutura do conflito parlamentar e da distância relativa entre situação e oposição. Em terceiro lugar, a governabilidade dependia do tamanho relativo dos partidos e da não negociabilidade de suas posições, em decorrência da sua maior ou menor radicalização ideológica. Não era possível determinar o número ótimo de partidos, nem verdade empírica na tese de que este último pudesse produzir um governo inteligente: "Quase tudo, em política, é possível, inclusive o oposto, desde que não seja necessariamente impossível" (Santos, 2007a:87). Irritava-o a pressuposição do senso comum elitista de acordo com a qual o político era sempre desonesto, e o eleitor, incapaz de agir de forma "racional" em função de sua falta de esclarecimento, de virtude cívica ou de altruísmo ${ }^{11}$. WGS também reconhecia que, apesar de resultarem de operações subjetivas indeterminadas, as preferências eleitorais costumavam ser fortemente influenciadas por identidades de classe (Santos, 2017a:142).

O interesse de WGS pelas instituições legislativas o conduziu ao estudo intenso e permanente dos sistemas partidários, coalizões, políticas legislativas, distribuição de cadeiras parlamentares, votações nominais e rotatividade das elites (Santos, 1986:174-175). Suas análises comprovavam a falta de razão de todos os defensores de reformas políticas, baseadas na pretensa superioridade do sistema eleitoral majoritário, da lista fechada, do monopólio partidário sobre as candidaturas e das cláusulas de barreira. Sistemas majoritários tinham tendência oligárquica e não democrática, porque violavam o ideal de correspondência entre a distribuição das preferências do eleitorado e a do poder parlamentar, asfixiando as minorias (Santos, 1994:6). Já o sistema proporcional, ao contrário, facilitava a dispersão das preferências e a expressão de variados segmentos da população. A multiplicidade de partidos, somada à lista aberta, acomodava o pluralismo de opiniões e democratizava as oportunidades de concorrência, reduzindo o poder das oligarquias partidárias. Cláusulas de barreira, por fim, só serviam às mesmíssimas oligarquias "para reduzir a competição e a representação político-partidárias" (Santos, 2007a:109). Em A difusão parlamentar do sistema partidário (2018), WGS alegava que os partidos pequenos investiam em distritos mais afastados, exercendo funções complementares às dos grandes em matéria 
de representação e de integração (Santos, 2018:55-57). As discussões sobre a excelência intrínseca das instituições, abstratamente consideradas, não tinham credibilidade científica:

Os sistemas eleitorais não filtram o caráter ou competência parlamentar, apenas traduzem a capacidade diferencial dos candidatos de acumularem votos. Não existe correspondência direta entre capacidade de acumular votos e competência parlamentar (Santos, 2007a:79).

Confundindo democracia com oligarquia representativa, os analistas superficiais se deixavam levar por "um cânone abstrato do que deveria ser um genuíno partido de representação" (Santos, 2018:29). Era preciso examinar de modo realístico, e não idealizado, o funcionamento dos partidos e o modo por que representavam os interesses dos eleitores:

A máxima realista de que os partidos são organizações para a conquista do poder não exclui, antes exige, que se responsabilizem pela formatação apropriada dos interesses difusos na comunidade. É a lógica da ação coletiva que, ao inibir a associação voluntária para ações de finalidades genéricas, propicia o estímulo à emergência de instituições especializadas preferencialmente na defesa de interesses universais de grupos particulares [...]. São os parlamentares, individualmente, que são mobilizados, assediados por eleitores em busca de simpatia e empenho na solução de seus problemas (Santos, 2018:161).

Democracia sob o ângulo da redistribuição (1): crítica do neoliberalismo e defesa da democracia social

No que concerne aos problemas de redistribuição, era preciso indagar sobre a possibilidade conciliar os valores da liberdade e da justiça na democracia. O Estado percebido como legítimo pela coletividade era aquele que garantia aos indivíduos que a compunham liberdade para realizar suas potencialidades, protegendo e adubando "a semeadura de múltiplos estilos de existência" (Santos, 2007a:93). WGS reconhecia, é certo, que a questão era complexa, porque a própria ideia de sociedade implicava a de desigualdade. A divisão social do trabalho impunha uma repartição desigual dos bens materiais, imateriais e de poder pelo mercado, tornando a interação social cooperativa e competitiva ao mesmo tempo. Embora não fossem autossuficientes, os 
indivíduos buscavam modificar a estrutura de distribuição das contingências sociais para melhorar suas possibilidades de realização. A vida social se sustentava em um paradoxo resultante de ações individuais que visavam a alterar a estrutura de desigualdades (competição) em um contexto de divisão do trabalho (cooperação). A percepção de legitimidade da democracia e, portanto, de sua estabilidade, dependiam de um tipo de interação que conciliasse os contrários, facultando a transformação molecular das hierarquias sem inviabilizar a possibilidade de cooperação. Semelhante tipo de interação democrática se convertia, desde logo, "em um ideal teleológico regulador, de onde derivam princípios de justiça para a avaliação da distribuição contemporânea das contingências sociais" (Santos, 1988a:25). Na prática, ao encarar o problema da redistribuição, independentemente de sua ideologia, todo governante se via compelido a guiar-se pelo "cálculo do dissenso", conceito desenvolvido por WGS em Cidadania e justiça (1979). O governante ficava premido pela estrutura de carências sociais que poderiam se converter em demandas, de um lado, e pela estrutura de recursos disponíveis, de outro. Era nessa situação delicada que o gestor público se via obrigado a decidir entre os apelos contraditórios por acumulação capitalista, vindos da direita, e aqueles de equidade social, vindos da esquerda. A realização do valor justo social não podia ser garantida por nenhum critério automático: qualquer que fosse a ideologia, o que se obtinha sempre era apenas a modificação relativa do perfil de desigualdades existentes.

WGS discordava das teorias que associavam diretamente desigualdade social e autoritarismo político: não era função das instituições representativas promover justiça econômica e social ${ }^{12}$. Do contrário, a democracia seria impossível em países pobres. Mas a justiça social e econômica era um resultado mais ou menos natural da democracia, sempre que praticada de modo leal e ininterrupto (Moreira, 2013:174). A instalação do maior número possível de atores em um regime de competição marcado pela igualdade de condições os impelia a fazer da política um meio de melhorar suas posições individuais na estrutura de oportunidades, escolhendo representantes que modelassem o Estado para atingir aquele fim. Absorvendo a massa de destituídos aos mecanismos de participação política, a democracia representativa aumentava inequivocamente a mobilidade social em relação aos regimes oligárquicos, porque a maioria passava a impelir o Estado a intervir no domínio socioeconômico. Era semelhante a compreensão do papel desempenhado pela democracia liberal na resolução de pro- 
blemas de distribuição que impunha ao analista ultrapassar a grade teórica do liberalismo clássico, conforme ele salientava em Paradoxos do liberalismo (1988a). Era uma fórmula que prosperara no século 19, porque facultava o progresso pela discussão do certo e do errado, com baixo custo de erro, no contexto de uma sociedade comercial. Porém, com a alteração do processo de divisão social do trabalho imposta pela industrialização, o liberalismo clássico se tornara insuficiente para sustentar o pluralismo político. A industrialização gerara um tipo novo de sociedade, elevando o custo dos erros, reduzindo o grau de previsibilidade social e criando um abismo social no que diz respeito à distribuição do conhecimento. Tudo propendia para o autoritarismo tecnocrático como fórmula de adaptação da sociedade ao novo mundo socioeconômico.

A democracia como regime livre e justo perigava seriamente, caso continuasse a ser pensada somente nos termos liberais clássicos da superada sociedade comercial. Desde o fim da Primeira Guerra Mundial, ficara claro que o problema da constituição de uma ordem democrática estável não podia ser dissociado daquele referente àquele de uma organização econômica conforme princípios de justiça social. Mas nenhum dos dois modelos concorrentes de sociedade - comunista ou capitalista - reproduzia com inteira correção o que se passava na ordem dos fatos, nem entregava o paraíso da emancipação. Também a resposta neoliberal de Hayek, Mises e Friedman lhe parecia absolutamente inapropriada para resolver o problema. Os neoliberais falhavam em comprovar a naturalidade do mercado e a incompatibilidade entre liberalismo político e intervenção estatal. Como Karl Polanyi demonstrara em A grande transformação, a ordem liberal nunca funcionara como queriam os neoliberais, que faziam uma reconstrução fantasiosa do modo porque o liberalismo oitocentista teria efetivamente funcionado. A "teoria positiva do Estado liberal" sempre pregara, desde o Iluminismo escocês, a intervenção moderada do governo, encarregando-o de adotar medidas tendentes a maximizar a produção e o consumo (Santos, 1978:9). Clássicos como David Hume e Adam Smith eram os primeiros a admitir a resolução das falhas do mercado pelo Estado. Deixados aos princípios neoliberais ortodoxos de Hayek e Friedman, a ordem liberal degenerava facilmente em oligarquia política e plutocracia econômica. A democracia despareceria debaixo da criação de barreiras à entrada da competição política, da captura das funções públicas por uns poucos, da distorção e da ineficiência na alocação de recursos, e da tendência à inflação e ao subemprego. 
Em outras palavras, o liberalismo político de WGS não se conciliava com o liberalismo econômico, entendido como a crença no mercado como exclusivo alocador de recursos e distribuidor de bens. Conforme ele ponderava em Teoria política e prospectos democráticos (1969), era preciso caminhar para uma teoria positiva do Estado democrático, que admitisse sua intervenção no domínio socioeconômico:

Que a teoria política possa ver como objetivo do governo, não a produção de funções compatíveis, mas o controle do processo de divisão do trabalho dirigido para a transformação cônscia do homem; e, nesta relação, os conflitos sobre valores se transformariam no próprio núcleo da política no processo de dirigir tal transformação (Santos, 1969:20).

Essa teoria positiva do Estado democrático desembocava inevitavelmente no modelo de democracia social encarnado no Welfare State que passou a vigorar no hemisfério norte/ocidental após a Segunda Guerra Mundial. Enquanto modelo de Estado encarregado dos problemas de redistribuição, a democracia social era percebida por WGS como o desaguadouro natural ("socialista") das práticas eleitorais da democracia liberal; uma alternativa prática aos modelos do socialismo comunista e de capitalismo puro, "duas grandes utopias em escombros" (Santos, 1978:124). Porque conciliava "os princípios de uma ordem livre com os princípios de uma ordem justa", a democracia social consistia no modelo socioeconômico mais próximo do ideal de justiça acalentado pela sociedade industrial (Santos, 1988a:15). Mas esse regime socioeconômico não caía do céu; ele carecia de um grande partido para ser construído:

Um regime democrático estável depende da existência de um partido socialista democrático forte, capaz de competir à direita contra os partidos que, em nome das liberdades humanas, desejam fazer sobreviver tanto quanto possível uma ordem social e economicamente injusta, e capaz de competir à esquerda contra os partidos que, em nome da justiça social, consideram a questão da democracia uma questão de tolos ou loucos. Partidos socialistas e democráticos tendem a se converter no centro político da história (Santos, 1979:16-17). 
Democracia sob o ângulo da redistribuição (2): as perspectivas sombrias da sociedade pós-industrial

Nos últimos anos, WGS retornou com força ao tema da associação entre democracia de massas e sociedade industrial. Conforme já referido, a industrialização convertera as oligarquias representativas em democracias de massas e substituíra o Estado mínimo pelo intervencionismo. Era toda essa dimensão "infraestrutural" do mundo social que dera vida à democracia social no século $X X$, que parecia ameaçada de desaparecimento no começo da centúria seguinte. A vitória do capitalismo sobre o socialismo, simbolizada pela queda do muro de Berlim, teria sido o desenlace de uma luta de séculos sobre a melhor maneira de organizar a vida em coletividade. O capitalismo sempre tivera de criar mecanismos que o compatibilizassem com os princípios éticos de organização social, representados sucessivamente pela escolástica, pelo contratualismo, pelo utilitarismo ou pelo socialismo. Todas obrigavam os empresários ou detentores do capital a limitarem seu potencial de exploração coativa da mão de obra, porque havia sempre outro modelo de sociedade que lhes servia de espantalho. A existência do comunismo como alternativa viabilizara ao longo do século XX o surgimento da democracia social, entendido como meio termo entre socialismo e capitalismo. Diante do fracasso na tentativa de criar uma sociedade moderna baseada no princípio da solidariedade, a utopia humanista vinha sendo dizimada por um capitalismo de pura acumulação e concentração de lucros: “O que se desfaz é a sociedade organizada e produtiva dos últimos três séculos, incluindo a viga fundacional de sua racionalidade operacional: a transitividade tácita nas relações econômicas, políticas, sociais, institucionais e pessoais" (Santos, 2017b:32). Tratava-se de "considerar a hipótese de que efetivamente nós estejamos em trânsito equivalente à ruptura que significou a revolução industrial em relação ao passado anterior da organização da vida material da humanidade" (Santos, 2019b:26). Em O epílogo da conciliação (2017b), WGS sugeria estar em curso um processo de reformulação radical de divisão social do trabalho em escala global, impulsionado pela revolução digital e da automação.

Havia diversos indícios da erosão da velha sociedade industrial. Para começar, a hegemonia do neoliberalismo não mais parecia ser apenas um soluço na história da democracia social. No passado, as crises econômicas eram debeladas por investimento público, políticas sociais voltadas para a geração de emprego, proteção ao trabalho, e 
inclusão das populações excluídas. Hoje, o que se percebe por toda a parte é a retirada do poder público e a eliminação da proteção social. Emergia uma subjetividade identitária extremada dos indivíduos, que o economicismo propunha compensar com uma objetividade radical extraída do materialismo das leis do mercado: "Dilaceradas, as pessoas transitam à velocidade suicida, da radical subjetividade, à objetividade tirânica" (Santos, 2017a:23). O ideal de um regime de liberdade e autonomia submergia diante da legitimação da riqueza sem limite e do poder sem constrangimentos. O espaço público, tal como conhecido nos últimos séculos, estava acabando. As acelerações temporais favoreciam a fragmentação social e complicavam o fluxo de informações e a capacidade de previsão dos atores. Quanto mais heterogênea a sociedade se percebia, maior o hiato entre a adesão mecânica às regras eleitorais e o repúdio a seus resultados. A nova divisão do trabalho imposta pela automação e pela revolução digital modificava a estruturação democrática em matéria de participação e integração. No mundo futuro, não só não haveria emprego para todos, como seriam pouquíssimos aqueles de qualidade. Noventa e cinco por cento da população viveria de renda mínima enquanto os outros cinco por cento dominariam o planeta. Em $A$ sociedade intransitiva (2017c), WGS criou um conceito novo para designar o mundo social emergente, marcado pelo fim das relações de solidariedade comunitária: o de sociedade intransitiva:

\begin{abstract}
A sociedade intransitiva é aquela em que a solidariedade faliu. A sociedade industrial transitiva contava com a adesão dos seus membros. O homem da sociedade transitiva vive e adere à transitividade das relações. $\mathrm{O}$ homem da sociedade intransitiva não gosta das relações intransitivas, mas não tem nenhuma condição de subvertê-las. Há a apatia do conformismo. A pessoa é obrigada a se virar por si própria. O vizinho é um competidor. E não há qualquer arena de conciliação (Santos, 2017b:38).
\end{abstract}

Poderia a democracia sobreviver à sociedade digital e da automação? WGS, que nunca acreditara na democracia como "fim da história" (Santos, 2007a:77), estava mais do que cético. A vertigem favorecia as reações conservadoras, entendidas como "mecanismos de defesa pessoais e sociais contra a ameaça de dissolução completa de uma semântica comunitária" (Santos, 2017a:22). Estava a caminho outra coisa, que os pósteros poderiam até chamar democracia, mas que seria muito diferente do que hoje entendemos por tal expressão ${ }^{13}$. 


\section{CONCLUSÃO}

O artigo apresentou uma visão de conjunto da ciência política de Wanderley Guilherme dos Santos a partir de uma perspectiva lógico-sistemática. Partiu da hipótese de que, em sua maturidade, ele desenvolveu uma teoria geral que o orientava no tratamento das questões mais específicas. Para comprová-la, foram recolhidas de suas obras as reflexões mais amplas nelas presentes, organizando-as e apresentando-as como peças de um mesmo mosaico, destacando sua considerável coerência. As considerações sobre o Brasil foram deixadas de lado. Em primeiro lugar, não seria possível incluí-las em apenas um artigo, face a uma obra tão vasta quanto a de WGS; em segundo lugar, acredito que elas poderiam ser compreendidas de modo mais adequado, caso se dispusesse preliminarmente de uma exposição de sua ciência geral. Nada impede, agora, que um segundo artigo, dedicado às reflexões de WGS sobre a política brasileira, seja produzido. Ele adotaria por analogia o itinerário aqui apresentado, começando por analisar a maneira como ele concebia as diferenças culturais entre o mundo anglo-saxão e a América Latina ${ }^{14}$. Na sequência, seria apresentada sua interpretação relativa ao pensamento político brasileiro e a influência que nela exerceram autores por ele admirados abertamente, como Oliveira Vianna e Guerreiro Ramos ${ }^{15}$. Na parte dedicada à mudança política, caberia descrever como WGS concebia a transição do Brasil semiautocrático do Império para a democracia, passando pela oligarquia da Primeira República, a democracia restrita de 1946-1964 e os intervalos autoritários do Estado Novo e do Regime Militar. Da mesma forma, um segundo artigo tentaria explicar como WGS encarava as sucessivas crises de integração, participação e redistribuição experimentadas pelo Brasil, abordando temas polêmicos, como o do suposto gigantismo do Estado e a coabitação de uma democracia pujante com um mundo de inércia cívica e social ${ }^{16}$.

Mas o autor também reconhece as limitações deste artigo, considerado o recorte escolhido. Não tendo sido possível esmiuçar os cinco tópicos, a apresentação resultou mais descritiva que o desejável. Poderiam ter sido mais bem explorados, sem dúvida, os pontos mais polêmicos ou provocativos da obra de WGS. Teria ele de fato substituído completamente o nacionalismo isebiano pelo paradigma da escolha pública? As aparentes determinações causais do mundo socioeconômico sobre os regimes políticos, presentes no seu chamado "materialismo", não enfraqueciam, no fundo, sua crença na autonomia das 
instituições políticas? Haveria compatibilidade entre as sequências do desenvolvimento suscitadas por Verba (integração, participação e distribuição) com os arquétipos sugeridos a partir de Dahl em sua a teoria da mudança política (autocracia, oligarquia e poliarquia)? Era o caso também de se perguntar se WGS não teria lido de forma demasiado descontextualizada a teoria do sistema representativo de José de Alencar, um dos expoentes do conservadorismo brasileiro. Ademais, não seria sua posição em relação às reformas políticas excessivamente conservadora, diante das disfuncionalidades das instituições brasileiras? Caso positivo, não teria sido ele cruel em sempre atribuir propósitos oligárquicos aos colegas que a propunham? Também seria legítimo questionar - sempre em tese - se WGS não minimizou o problema da governabilidade no quadro de um sistema partidário radicalmente fragmentado como o brasileiro. Todas estas eram questões que, aqui ventiladas por amor ao debate, mereciam sem dúvida uma reflexão mais detida. Resta-me o consolo de recordar uma de suas máximas em matéria de pesquisa, formulada por exímio conhecedor de sua obra: "O valor de um trabalho científico reside, mais do que na capacidade de nos convencer sobre a veracidade de um argumento, na descoberta de perguntas que ainda não nos tínhamos feito e que assomam como centrais" (Santos, 2018:18).

É possível concluir, pelo menos, discutindo um ponto polêmico: a aparente incongruência de perspectivas ideológicas presentes na obra de WGS. Ao longo de sua carreira, foi acusado pela direita de ser esquerdista; pelos liberais de ser autoritário; pela esquerda de ser liberal. Acusações que, no conjunto, revelam involuntariamente o lugar em que ele de fato se achava: o de um defensor de uma democracia de massas, dotada de sólidas instituições representativas e competitivas, completada por um Estado socialmente atuante. No campo acadêmico, foi a aparente incongruência entre conservadorismo institucional e elogio da criatividade que chamou a atenção de um estudioso de sua obra (Araújo, 2019:198). De fato, a democracia de WGS consegue ser, simultaneamente, libertária em matéria civil e política, institucionalmente conservadora, e socialista em matéria social. Mas não vejo aí incongruência, caso esse posicionamento seja examinado à luz do seu conceito de "democracia natural". Em um mundo governado pela "mão invisível do caos", rebelde a qualquer previsão ou planificação, a "democracia natural" era a fórmula política que melhor assegurava aos humanos um ambiente de liberdade e criatividade. Deixada livre da ingerência de arrogantes e desastrados 


\section{Christian Edward Cyril Lynch}

engenheiros constitucionais, desenvolvendo-se "naturalmente" no caminho do alargamento da participação e da competição eleitorais, a democracia se pautava por uma dinâmica que incentivava a liberdade individual, a mobilidade social e a redução das desigualdades. A defesa de semelhante "democracia natural", que podia ter lugar nas ruas, mas devia ser minimamente filtrada pelas instituições, impunha ao verdadeiro democrata - quanto mais se socialista - que fosse conservador em matéria de reforma política. Porque era grande o risco de que as alterações trouxessem retrocessos. A finalidade desse "conservadorismo" não era outro, senão preservar a maravilhosa dimensão de "anomalia" do regime democrático, que lhe permitia compatibilizar a liberdade mais extrema com a possibilidade concreta de progresso social. Era o que WGS explicava em sua apaixonada profissão de fé democrática intitulada $A$ anomalia democrática: adolescência e romantismo na história política (1998):

Os produtores de poder, hoje, como sempre, são aqueles que não abdicam de afirmar que o poder constituinte é algo que não se transfere; que há uma distinção entre o poder constituinte e poder legislativo; e que, se foi a subjetividade que levou à democracia, também é essa subjetividade que impõe permanentemente a necessidade de novos experimentos, de novas formas de interação, de novas reflexões sobre o que ocorre, de propostas utópicas; que impõe a liberdade interna de pensar, de ousar e de tentar instaurar a quebra de rotina. Os produtores de poder são os irredentos de sempre, são os irredentos de hoje, submetidos pela força, pela ameaça da coação, mas que jamais abdicaram de sua liberdade interior, nem mesmo quando privados da sua liberdade exterior. [...]. Só estes é que, a cada momento, transcendem e têm a coragem e a ousadia de tentar transcender o dado, o institucionalizado, de desprezar e não se intimidar com o estigma, com a discriminação, com ostracismo, com a difamação, com a calúnia, com a infâmia, com o assassinato de caráter. É nos irredentos que sempre se fundou, sempre se funda e sempre se fundará a democracia (Santos, 1998c:7).

(Recebido para publicação em 21 de dezembro de 2019) (Aprovado para publicação em 1 de março de 2020) 


\section{NOTAS}

1. Em entrevista concedida em 2013, depois de minimizar seu papel na fundação da "nova" Ciência Política brasileira, atribuindo-a a toda uma geração, Wanderley afirmou: "Também não terei falsa modéstia e dizer que não tive nessa tarefa, ou nesse período, um papel importante. Tive. Por aptidão, ou por circunstância, ou por desempenho, por trabalho, por esforço, por ocasião, uma série de coisas" (Moreira, 2013:170).

2. Antes de sistematizadas no Discurso sobre o objeto (1990), as ideias de Wanderley Guilherme sobre a ignorância radical relativamente ao funcionamento do mundo social foram antes expostas em três textos: Em defesa do laissez-faire: um argumento provisório (1979), que se tornaria o primeiro capítulo dos Paradoxos do Liberalismo (1988); Teoria social e análise de políticas públicas, primeiro capítulo de Cidadania e Justiça (1979); e Economia e ignorância: notas prévias sobre uma disciplina agônica (1990).

3. A crítica às escolas se estendia aos subcampos do conhecimento que the pareciam deficientemente estruturados, como os de comportamento eleitoral, desenvolvimento político e economia. As hipóteses desenvolvidas por seus colegas daqueles campos lhe pareciam normativas e não científicas; suas hipóteses de trabalho eram equivocadas, e os métodos escolhidos estavam trocados (Santos, 1971a; 1971b e 1990).

4. A coerência do posicionamento de WGS fica mais clara quando ele enuncia jamais ter sido "marxista, no sentido ortodoxo e sistemático da palavra [...]. Para mim, o marxismo não dava conta de todas as questões que eu tinha na minha cabeça de natureza teórica, de natureza histórica [...]. Utilizava, como utilizo, sempre que necessário [...]. Aliás, eu não sou nada sistematicamente. Nenhuma escola sistematicamente nunca me satisfez. Estou a aberto a qualquer, a todas as ideias, até me persuadirem" (Moreira, 2013:163-164).

5. Na mesma entrevista antes referida, WGS diria a respeito da importância da história na formação do cientista político: "O cientista político aprende pouco a história [...]. O desconhecimento leva a uma fragilidade de análise, tomando-se, às vezes, muitas coisas como universais, quando não são, e outras, quando são, como absolutamente triviais. [...]. Então, você, muitas vezes, tem de fazer um papel duplo; você tem que fazer o papel de historiador para descobrir os fatos, para depois fazer análise política, sociológica, se quiser. Mas você tem que ter a formação apropriada para isso". E arrematava: "O cientista político que quiser trabalhar bem vai ter que fazer um trabalho artesanal de historiador” (Moreira, 2013:172-173).

6. Tudo considerado, WGS criara na pós-graduação do antigo IUPERJ duas disciplinas obrigatórias dedicadas ao estudo da teoria política, entendida como uma história da ciência política. A primeira se chamava Teoria Política I ou Básica, começando em Maquiavel e terminando em Tocqueville e Marx (“os clássicos”). A segunda se chamava Teoria Política II ou Contemporânea e, partindo de Mosca e Pareto, concluía com Buchanan, Olson e Dahl (“os modernos").

7. Redimensionado e ampliado, o artigo A lógica dual da ação coletiva foi depois republicado como o segundo capítulo de Razões da desordem (1993c).

8. "Ainda considero a teoria poliárquica de Robert Dahl, mesmo com as imperfeições que possa ter, como a mais econômica e eficiente reflexão para entender as sociedades democráticas contemporâneas. Não conheço nenhum ponto de partida mais rico e desafiador" (Moreira, 2013:173). Por ocasião do falecimento de Dahl, WGS o homenageou em um pequeno artigo chamado Robert Dahl econômico (2014). 


\section{Christian Edward Cyril Lynch}

9. “A copiosa literatura sobre rupturas, transições, consolidações, democracias da terceira onda etc. não passa de ornamental código de linguagem cujo valor explicativo e preditivo é praticamente igual a zero. Do ponto de vista botânico-classificatório, o que tem ocorrido é simplesmente uma inflação vocabular, associada à confusão mais do que ao esclarecimento. Ademais, a análise da complexidade do fenômeno democrático foi reduzida à mera propaganda do sistema parlamentarista e do sistema eleitoral majoritário" (Santos, 1998a:24).

10. "São os efeitos da operacionalidade poliárquica em culturas políticas oligárquicas, ainda que representativas, que geram a desfiguração de um problema real e naturalmente democrático - o de reconciliar conflitos e garantir a cooperação produtiva entre milhões de seres humanos isonômicos (porque iguais perante a lei) -, convertendo em suposta patologia crismada de 'crise de governabilidade' em sentido forte, particularmente de governabilidade parlamentar, ou seja, de governabilidade representativa" (Santos, 2007a:77).

11. "O eleitor sabe quando uma eleição está longe de ser competitiva e tem seus resultados combinados de antemão, quando o excesso de partidos no governo dificulta a administração pública e quando de 'democrático' um país só se apropriou, indebitamente, do adjetivo" (Santos, 2007b:9).

12. "A tradicional hipotética atenção entre democracia e desigualdades econômicas só ocorre, de fato, em situações limite, nas quais a pobreza vira miséria, a miséria se converte em fome endêmica e, esta, em inevitável mortandade [...]. As conexões entre o perfil distributivo da economia e as irregulares marés da política, especialmente da política democrática, existem, sem dúvida, mas resultam de contiguidade as causas distintas daquelas que são privilegiados pela literatura estritamente economista. [...]. Os números insistem em revelar que as distâncias relativas entre pobres e ricos ou aumentam ou permanecem as mesmas, independentemente do sistema político dos países comparados. Existe mais mobilidade e alternância entre os países pobres do que entre os países ricos entre si e entre os ricos e os países pobres" (Santos, 2007a:16,17 e 31).

13. O retorno de WGS ao principal tema isebiano de sua mocidade, que vinculava a industrialização à democracia, coincidiu com sua última mudança de endereço: ele instalou-se em Botafogo a poucos passos da antiga sede do ISEB (hoje museu do Índio), na rua das Palmeiras, e a apenas a uma quadra do seu sucessor, o antigo IUPERJ - onde atuamente funciona o IESP-UERJ - situado na rua da Matriz. Neste último, ofereceu em seu último semestre de vida um curso voltado justamente para compreender a formação da sociedade industrial.

14. A questão da América Latina aparece em artigos como Paradigma e história: a ordem burguesa na imaginação social brasileira (1978); A ciência política na América Latina (notas preliminares de autocritica) (1980); Autoritarismo e após: convergências e divergências entre Brasil e Chile (1982); O século de Michels: competição oligopólica, lógica autoritária e transição na América latina (1985) e Brasil X Estados Unidos: é a paixão que nos separa (1986).

15. Para WGS, Oliveira Vianna era "sem dúvida, o mais arguto, multifacético e criativo ensaísta brasileiro deste século (i.e., XX). À sua sombra redefinem-se a abordagem e a temática da análise da sociedade brasileira, que muda de qualidade a partir da década de 1930, dando origem a rico filão ensaístico de todo tipo" (Santos, 1998a:61). O conjunto de artigos seus sobre pensamento político brasileiro foi reunido no volume $A$ imaginação política brasileira (2017).

16. As principais obras dedicadas ao estudo da trajetória política e social brasileira: Razões da desordem (1993c), Décadas de espanto e uma apologia democrática (1998), Horizonte do desejo: instabilidade, fracasso coletivo e inércia social (2004), e O ex-Leviatã brasileiro: do voto disperso ao clientelismo concentrado (2006). 


\section{REFERÊNCIAS}

ANASTASIA, Fatima. (2013), “Considerações sobre as curvas da política”. In: O. Dulci (org.), Leituras críticas sobre Wanderley Guilherme dos Santos. 1aㅡ. Belo Horizonte: UFMG/Perseu Abramo, pp. 95-120.

ARAÚJO, Cícero. (2019), "Wanderley Guilherme dos Santos: ontologia e política". In: W. G. dos Santos, Discurso sobre o objeto: uma poética do social. $2^{a}$. edição revista e aumentada. Rio de Janeiro: Topbooks, pp. 121-158.

AVRITZER, Leonardo; MILANI, Carlos Roberto Sanchez; BRAGA, Maria do Socorro (orgs.). (2016), A Ciência Política no Brasil 1960-2015. Rio de Janeiro: FGV Editora.

COHN, Amélia (org.). (2015), Encontros com Wanderley Guilherme dos Santos. Rio de Janeiro: Azougue.

DULCI, Otávio Soares (org.). (2013), Leituras críticas sobre Wanderley Guilherme dos Santos. Col. Intelectuais do Brasil, Belo Horizonte, Ed. UFMG e São Paulo, Ed. Fundação Perseu Abramo.

FORJAZ, Maria Cecília Spina. (1997), “A emergência da Ciência Política acadêmica no Brasil: aspectos institucionais". Revista Brasileira de Ciências Sociais, v. 12, n. 35.

LYNCH, Christian Edward Cyril. (2013), “The institutionalization of Brazilian political thought in the social sciences: Wanderley Guilherme dos Santos' research revisited (1963-1978)". Brazilian Political Science Review, v. 7, n. 3, pp. 36-60.

. (2017), “Entre a 'velha' e a 'nova' Ciência Política: continuidade e renovação acadêmica na primeira década da Revista DADOS (1966-1976)". DADOS - Revista de Ciências Sociais, v. 60, n. 3, pp. 663-702.

MOREIRA, Marcelo Sevaybricker. (2013), “Entrevista com Wanderley Guilherme dos Santos". In: O. Dulci (org.), Leituras críticas sobre Wanderley Guilherme dos Santos. $1^{\mathrm{a}}$ ed. Belo Horizonte: UFMG/Perseu Abramo.

- (2014), "A poliarquia brasileira e a reforma política: análise de uma contribuição de Wanderley Guilherme dos Santos à Teoria Política". DADOS - Revista de Ciências Sociais, v. 57, n. 2, pp. 293-323.

. (2020), O pensamento político de Wanderley Guilherme dos Santos. Belo Horizonte: Scriptum.

SANTOS, Fabiano. (2018), "Prefácio". in: W. Guilherme dos Santos, A difusão parlamentar do sistema partidário: exposição do caso brasileiro. Rio de Janeiro: Editora UFRJ.

SANTOS, Wanderley Guilherme dos. (1963a), Reforma contra reforma. Rio de Janeiro: Tempo Brasileiro.

. (1963b), Introdução ao estudo das contradições sociais no Brasil. Rio de Janeiro: ISEB.

. (1965), "Preliminares de uma controvérsia sociológica". Revista Civilização Brasileira, n. $5 / 6$, pp. $53-81$.

. (1967), "Estudos sobre a teoria da demonstração (1): a teoria da agressão de Johan Galtung". DADOS - Revista de Ciências Sociais, n. 2-3, pp. 133-149. 


\section{Christian Edward Cyril Lynch}

(1969), "Teoria política e prospectos democráticos". DADOS - Revista de Ciências Sociais, n. 6, pp. 5-23.

(1971a), "Eleição, representação, política substantiva". DADOS - Revista de Ciências Sociais, n. 8, pp. 7-25.

. (1971b), "Explicação e predição de desenvolvimento político: um exercício em construção teórica". Revista de Administração de Empresas, v. 11, n. 3, pp. 65-76.

. (1977), Poder e política: crônica do autoritarismo brasileiro. Rio de Janeiro: Forense Universitária.

. (1978), Ordem burguesa e liberalismo político. São Paulo: Duas Cidades.

. (1979), Cidadania e justiça: a polícia social na ordem brasileira. Rio de Janeiro: Campus.

. (1985), “O Século de Michels: Competição Oligopólica, Lógica Autoritária e Transição na América Latina". DADOS - Revista de Ciências Sociais, v. 28, n. 3, pp. 283-310.

. (1986), Sessenta e quatro: anatomia da crise. Rio de Janeiro: Vértice/Iuperj.

(1987), Crise e castigo: partidos e generais na politica brasileira. Rio de Janeiro: Vértice/ Iuperj.

. (1988a), Paradoxos do liberalismo. Rio de Janeiro: Vértice/Iuperj.

(1988b), “Quem dará o golpe no Brasil?". In: N. Valadares de Carvalho (org.), Trilogia do terror: a implantação (1964). Rio de Janeiro: Vértice/RT.

. (1990a), Discurso sobre o objeto: uma poética do social. São Paulo: Companhia das Letras.

. (1990b), "Economia e ignorância: notas prévias sobre uma disciplina agônica". Nova Economia, v. 1, n. 1, pp.9-33.

. (1993a), Regresso: máscaras institucionais do liberalismo oligárquico. Rio de Janeiro: Opera Nostra.

. (1993b), “A cabala oligárquica". In: L. Martins Rodrigues et al (org.), Em defesa do presidencialismo. Rio de Janeiro: Espaço e Tempo, pp. 53-75.

. (1993c), Razões da desordem. $3^{\mathrm{a}}$. ed. Rio de Janeiro: Rocco.

. (1997), “Da oligarquia à poliarquia: competição eleitoral e processos não-encarceráveis". Série Estudos, 95. Rio de Janeiro, IUPERJ.

. (1998a), Décadas de espanto e uma apologia democrática. Rio de Janeiro: Rocco.

(1998b), "Poliarquia em 3D". DADOS - Revista de Ciências Sociais, v. 41, n. 2, pp. 37-56.

. (1998c), "A anomalia democrática: adolescência e romantismo na história política". Revista Brasileira de Ciências Sociais, v. 13, n. 36.

. (2003), O cálculo do conflito: estabilidade e crise na política brasileira. Belo Horizonte: Editora da UFMG.

. (2007a), O paradoxo de Rousseau: uma interpretação democrática da vontade geral. Rio de Janeiro: Rocco.

DADOS, Rio de Janeiro, vol.63(1):e20200031, 2020. 
. (2007b), Governabilidade e democracia natural. Rio de Janeiro, FGV Editora.

. (2014), "Robert A. Dahl, Econômico". DADOS - Revista de Ciências Sociais, v. 57, n.2, pp. 289-292.

. (2017), A democracia impedida: o Brasil no século XXI. Rio de Janeiro: FGV Editora.

. (2017b), “O epílogo da conciliação: a supremacia do 'eu' sobre o 'nós'”. Revista Insight Inteligência, n. 79, pp.30-41.

. (2017c), "A sociedade intransitiva: arqueologia constitucional do século XIX". Revista Insight Inteligência, n. 79, pp.42-46.

. (2018), A difusão parlamentar do sistema partidário: exposição do caso brasileiro. Rio de Janeiro: Editora UFRJ.

. (2019), Discurso sobre o objeto: uma poética do social. $2^{\mathrm{a}}$. edição revista e aumentada. Rio de Janeiro: Topbooks.

. (2019b), "Uma lição magna: derradeiros ensinamentos do professor Wanderley Guilherme dos Santos". Revista Insight Inteligencia, n. 87, pp. 22-36. 


\section{Christian Edward Cyril Lynch}

\section{RESUMO}

Um Pensador da Democracia: Introdução à Ciência Politica de Wanderley Guilherme dos Santos

O presente artigo apresenta uma visão lógico-sistemática do conjunto da ciência política de Wanderley Guilherme dos Santos. Justifica-se a empreitada pela importância de sua obra na fundação e desenvolvimento da nova ciência política brasileira desde a década de 1960, e na carência de estudos de maior fôlego a respeito dela. São examinados quatro pontos de sua ciência política: 1) Filosofia social, em suas dimensões ontológica e epistemológica; 2) Teoria política, descrevendo o papel dos clássicos e dos modernos; 3) Teoria da mudança política, contando com uma tipologia de regimes, suas modalidades de trânsito de um para outro, bem como as hipóteses de reforma e ruptura; e 4) Teoria da democracia, contemplada em suas três dimensões: integração, participação e redistribuição. Espera-se que o presente texto sirva de ponto de partida para futuros aprofundamentos de cada um dos itens referidos.

Palavras-chave: Wanderley Guilherme dos Santos; ciência política; pensamento político brasileiro; instituições; democracia

\section{ABSTRACT \\ A Democracy Thinker: An Introduction to Wanderley Guilherme dos Santos' Political Science}

This article presents a logical and systematic view of Wanderley Guilherme dos Santos' body of work in Political Science. The endeavor is justified by the importance of his work in the foundation and development of the new Brazilian Political Science since the 1960s, and furthermore in the lack of deeper studies about it. We will examine four points of his Political Science: 1) Social Philosophy, in its ontological and epistemological dimensions; 2) Political Theory, describing the role of classics and moderns; 3) Theory of political change, relying on a typology of regimes, their modes of transit from one to another, as well as the hypotheses of reform and rupture; and 4) Democracy theory, covering its three dimensions: integration, participation, and redistribution. The goal is for this article to serve as a starting point for further studies of each one of the issues addressed.

Keywords: Wanderley Guilherme dos Santos; Political Science; Brazilian political thought; institutions; democracy 


\section{RÉSUMÉ \\ Un Penseur de la Démocratie: Introduction à la Science Politique chez Wanderley Guilherme dos Santos}

Cet article présente une vision logique et systématique de l'ensemble des sciences politiques de Wanderley Guilherme dos Santos. L'effort est justifié par l'importance de son travail dans la fondation et le développement de la nouvelle Science Politique brésilienne depuis les années 1960, et par le manque d'études plus importantes à ce sujet. Quatre points de sa oeuvre sont examinés: 1) Philosophie Sociale, dans ses dimensions ontologiques et épistémologiques; 2) Théorie Politique, décrivant le rôle des classiques et des modernes; 3) Théorie du Changement Politique, s'appuyant sur une typologie des régimes, leurs modes de transition de l'un à l'autre, ainsi que les hypothèses de réforme et de rupture; et 4) Théorie de la Démocratie, envisagée dans ses trois dimensions: intégration, participation et redistribution. Nous espérons que ce texte servira de point de départ pour une étude plus approfondie de chacun des points mentionnés.

Mots-clés: Wanderley Guilherme dos Santos; Science Politique; pensée politique brésilienne; institutions; démocratie

\section{RESUMEN \\ Un Pensador de la Democracia: Introducción a la Ciencia Política de Wanderley Guilherme dos Santos}

El presente artículo presenta una visión lógico-sistemática del conjunto de la ciencia política de Wanderley Guilherme dos Santos. Se justifica este esfuerzo por la importancia de su obra en la fundación y el desarrollo de la nueva ciencia política brasilera desde la década de 1960, y en la carencia de estudios de mayor aliento sobre esta disciplina. Son examinados cuatro puntos de su ciencia política: 1) Filosofía social, en sus dimensiones ontológica y epistemológica; 2) Teoría política, describiendo el papel de los clásicos y de los modernos; 3) Teoría del cambio político, contando con una tipología de regímenes, sus modalidades de tránsito de uno para otro, así como las hipótesis de reforma y ruptura; y 4) Teoría de la democracia, contemplada en sus tres dimensiones: integración, participación y redistribución. Se espera que el presente texto sirva de punto de partida para futuras profundizaciones de cada uno de los puntos referidos.

Palabras clave: Wanderley Guilherme dos Santos; ciencia política; pensamiento político brasilero; instituciones; democracia 